\title{
HYDROGEOLOGY AND \\ WATER QUALITY OF THE \\ NORTH CANADIAN RIVER ALLUVIUM, \\ CONCHO RESERVE, CANADIAN \\ COUNTY, OKLAHOMA
}

By Carol J. Becker

U. S. DEPARTMENT OF INTERIOR

U.S. GEOLOGICAL SURVEY

Open-File Report 97-657

Prepared in cooperation with the Cheyenne and Arapaho Tribes of Oklahoma

Oklahoma City, Oklahoma

1998 


\section{U.S. DEPARTMENT OF THE INTERIOR \\ BRUCE BABBITT, Secretary}

U.S. GEOLOGICAL SURVEY

THOMAS J. CASADEVALL, Acting Director

Any use of trade names in this publication is for descriptive purposes

only and does not imply endorsement by the U.S. Government.

UNITED STATES GOVERNMENT PRINTING OFFICE: OKLAHOMA CITY 1998

For additional Information write to:

District Chief

U.S. Geological Survey

Water Resources Division

202 NW 66th Street, Building 7

Oklahoma Clty, OK 73116
Copies of this report can be

purchased from:

U.S. Geological Survey

Branch of Information Services

Box 25286

Denver, CO 80225-0286 


\section{CONTENTS}

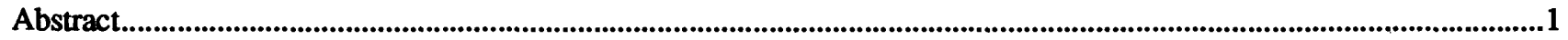

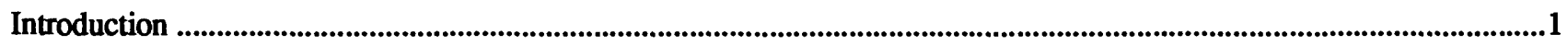

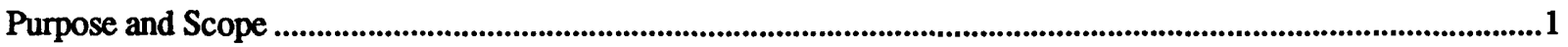

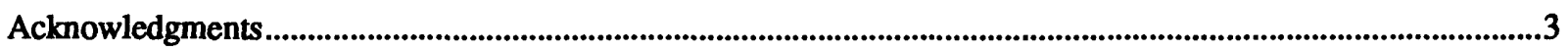

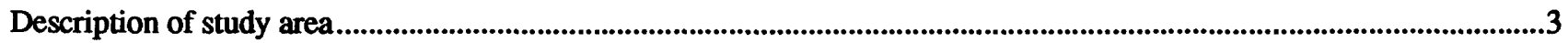

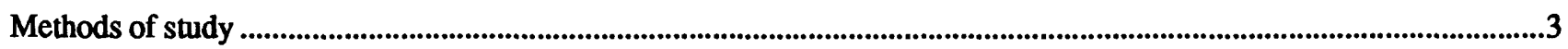

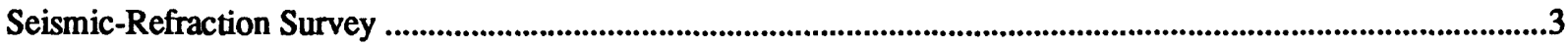

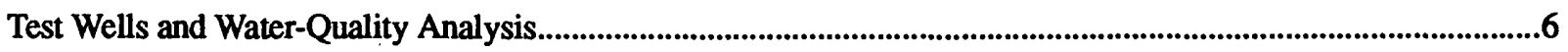

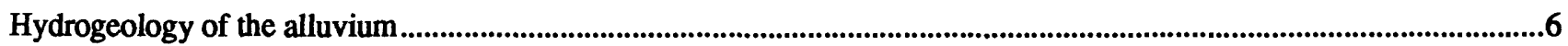

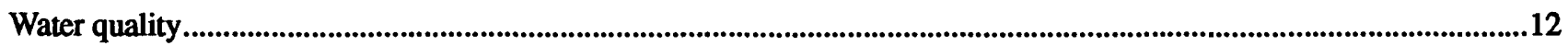

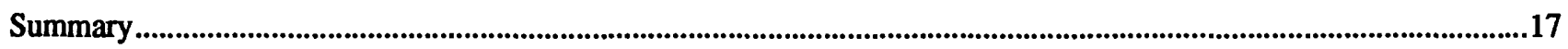

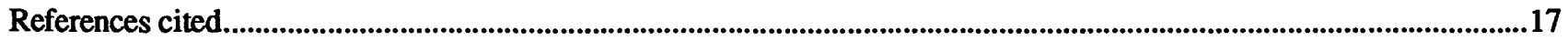

\section{ILLUSTRATIONS}

Figures:

1-5. Maps showing:

1. Location of study area, North Canadian River and the Concho Reserve in Canadian

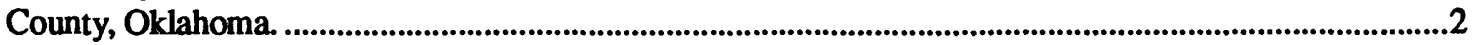

2. Geologic units and area of investigation within the Concho Reserve, Canadian

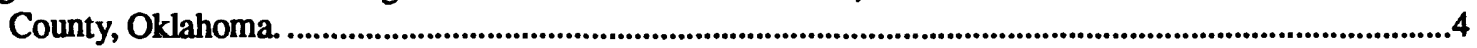

3. Location of seismic lines, test wells, and irrigation well within the Concho Reserve study area, Canadian County, Oklahoma. ..............................................................................................................5

4. Altitude of the bedrock surface within the Concho Reserve study area in Canadian County, Oklahoma. ..........10

5. Thickness of alluvial deposits within the Concho Reserve study area in Canadian County, Oklahoma...............11

6. Generalized section of the North Canadian River alluvial aquifer, Concho Reserve study area

in Canadian County, Oklahoma, using natural gamma-ray logs.....................................................................13

7-8. Maps showing:

7. Potentiometric surface of the North Canadian River alluvial aquifer within the Concho Reserve study area, Canadian County, Oklahoma, February 2, 1995.......................................................................................14

8. Areas subject to ponding or elevated water table on the North Canadian River alluvium within the Concho Reserve study area, Canadian County, Oklahoma.

\section{TABLES}

1. Hydrologic data interpreted from seismic-refraction survey performed on the North Canadian River alluvium, Concho Reserve, Canadian County, Oklahoma, in July and August 1993

2. Well-site information and depth to water measured in wells completed in the North Canadian River alluvium, Concho Reserve, Canadian County, Oklahoma

3. Field water-quality measurements collected February 1, 1994, in wells completed in the North Canadian River alluvium, Concho Reserve, Canadian County, Oklahoma 
4. Measured concentrations of constituents exceeding the secondary maximum contaminant levels set for drinking water by the U.S. Environmental Protection Agency (1994) and the Oklahoma State Department of Environmental Quality (1992) in a ground-water sample collected February 1, 1994, from test well TW-4 completed in the North Canadian River alluvium, Concho Reserve, Canadian County, Oklahoma

5. Laboratory measured water-quality properties, bacteria counts, major ion and nutrient concentrations, trace-element and radionuclide concentrations, and organic compound concentrations in a ground-water sample collected February 1, 1994, from test well TW-4 completed in the North Canadian River alluvium, Concho Reserve, Canadian County, Oklahoma 19

\section{CONVERSION FACTORS AND VERTICAL DATUM}

\begin{tabular}{rrll}
\hline \hline & By & To obtaln \\
\hline Multiply & & & \\
\hline inch (in) & 2.54 & centimeter \\
foot (ft) & 0.3048 & meter \\
mile (mi) & 1.609 & kilometer \\
& foot per second (ft/s) & 0.3048 & meter per second \\
grain (gr) & 0.0648 & gram \\
\hline
\end{tabular}

Temperature in degrees Celsius $\left({ }^{\circ} \mathrm{C}\right)$ may be converted to degrees Fahrenheit $\left({ }^{\circ} \mathrm{F}\right)$ as follows:

${ }^{\circ} \mathrm{F}=1.8^{\circ} \mathrm{C}+32$

Temperature in degrees Fahrenheit $\left({ }^{\circ} \mathrm{F}\right)$ may be converted to degrees Celsius $\left({ }^{\circ} \mathrm{C}\right)$ as follows:

$$
{ }^{\circ} \mathrm{C}=\left({ }^{\circ} \mathrm{F}-32\right) / 1.8
$$

Chemical concentration and water temperature are given in metric units. Chemical concentration in water is given in milligrams per liter $(\mathrm{mg} / \mathrm{L})$ or micrograms per liter $(\mu \mathrm{g} / \mathrm{L})$. Milligrams per liter is a unit expressing the solute per unit volume (liter) of water. One thousand micrograms per liter is equivalent to 1 milligram per liter. Specific conductance is given in microsiemens per centimeter $(\mu \mathrm{S} / \mathrm{cm})$ at 25 degrees Celsius. Radioactivity is expressed picoCuries per liter ( $\mathrm{pCi} / \mathrm{L}$ ), the amount of radioactive decay producing 2.2 disintegrations per second in a unit volume (liter) of water.

Sea level: In this report, "sea level" refers to the National Geodetic Vertical Datum of 1929 (NGVD of 1929)—a geodetic datum derived from a general adjustment of the first-order level nets of both the United States and Canada, formerly called Sea Level Datum of 1929. 


\section{Explanation of the Site-Numbering System}

Locations of data sites are specified by latitude and longitude to the nearest second and by a local identifier, which is its public land-survey location in Oklahoma. The location is described by a particular township, range, and quarter-quarter-quarter section. The township numbers are north of the 3rd parallel and the range numbers are west of the Indian Meridian. A section is equal to 1 square mile and as shown below, the fractional parts are given from larger to smaller areas of the section. The final digit (1) is the sequential number of a well within the smallest fractional subdivision (10 acres, in the example shown).

R. $07 \mathrm{~W}$.

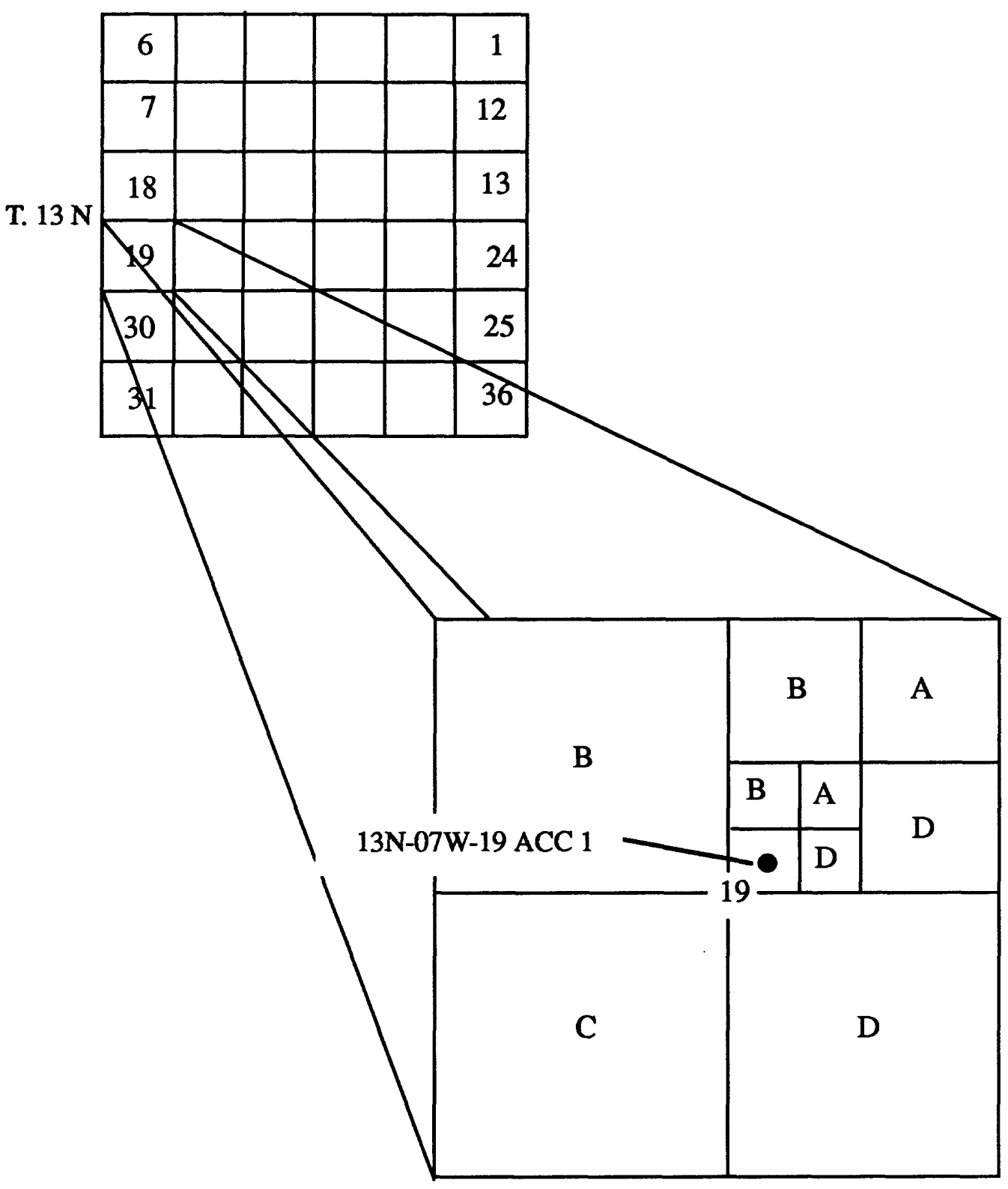




\title{
Hydrogeology and Water Quality of the North Canadian River Alluvium, Concho Reserve, Canadian County, Oklahoma
}

\author{
By Carol J. Becker
}

\section{Abstract}

A growing user population within the Concho Reserve in Canadian County, Oklahoma, has increased the need for drinking water. The North Canadian River alluvium is a reliable source of ground water for agriculture, industry, and cities in Canadian County and is the only ground-water source capable of meeting large demands. This study was undertaken to collect and analyze data to describe the hydrogeology and ground-water quality of the North Canadian River alluvium within the Concho Reserve.

The alluvium forms a band about 2 miles long and 0.5 mile wide along the southern edge of the Concho Reserve. Thickness of the alluvium ranges from 19 to 75 feet thick and averages about 45 feet in the study area. Well cuttings and natural gamma-ray logs indicate the alluvium consists of interfingering lenses of clay, silt, and sand. The increase of coarse-grained sand and the decrease of clay and silt with depth suggests that the waterbearing properties of the aquifer within the study area improve with depth. A clay layer in the upper part of the aquifer may be partially responsible for surface water ponding in low areas after above normal precipitation and may delay the infiltration of potentially contaminated water from land surface.

Specific conductance measurements indicate the ground-water quality improves in a northern direction towards the terrace. Water-quality properties, bacteria counts, major ion and nutrient concentrations, trace-element and radionuclide concentrations, and organic compound concentrations were measured in one ground-water sample at the southern edge of the Concho Reserve and comply with the primary drinking-water standards.

Measured concentrations of iron, manganese, sulfate, and total dissolved solids exceed the secondary maximum contaminant levels set for drinking water. The ground water is a calcium sulfate bicarbonate type and is considered very hard, with a hardness of 570 milligrams per liter as calcium carbonate.

\section{INTRODUCTION}

The Concho Reserve in Canadian County, Oklahoma has an increased need for drinking water. The North Canadian River alluvium supplies most of the municipal, industrial, and irrigation water for the surrounding area, and is the only ground-water source capable of meeting large demands (Bergman and Savoca, 1993). In an effort to provide information that can be used to facilitate the development and management of the alluvial aquifer for future ground-water supplies, the U.S. Geological Survey, in cooperation with the Cheyenne and Arapaho Tribes of Oklahoma, collected data on the hydrogeology and ground-water quality of the North Canadian River alluvium within the Concho Reserve in Canadian County, Oklahoma (fig. 1) from July 1993 to May 1994.

\section{Purpose and Scope}

The purpose of this report is to describe the hydrogeology and ground-water quality of the North Canadian River alluvium located in the northern half of sections 19 and 20, township 13 north, range 7 west within the Concho Reserve in Canadian County, Oklahoma (fig. 1).

The scope of the work included data collected from a seismic-refraction survey and six test wells completed in the alluvium. Thickness of the alluvial deposits, bedrock altitude, water-level altitudes, and areas on the alluvium prone to surface-water ponding or high water-table conditions are illustrated on maps. A section from natural gamma-ray logs illustrates the lithologic character of the aquifer along the line of sec- 


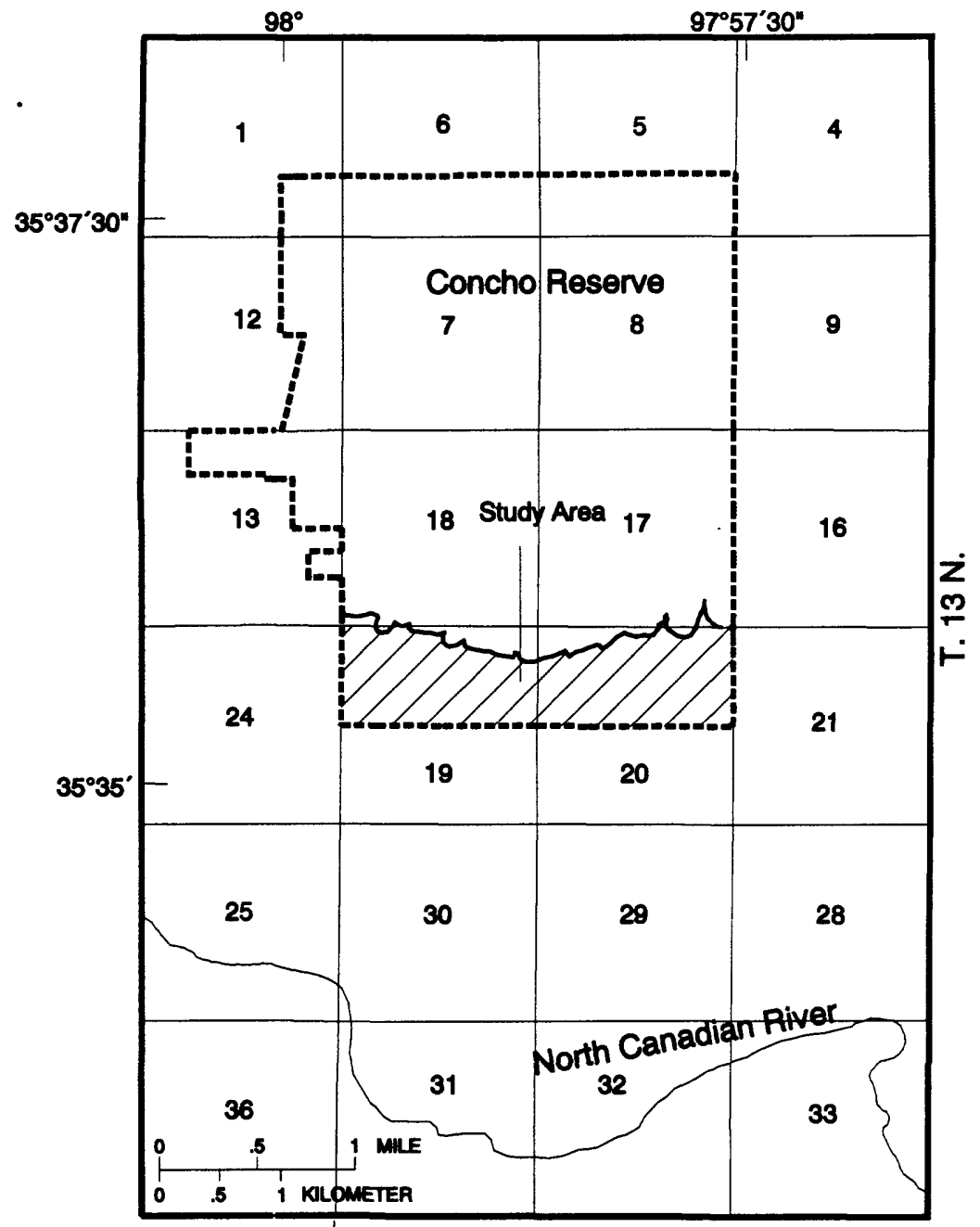

R. 8 W. R. 7 W.

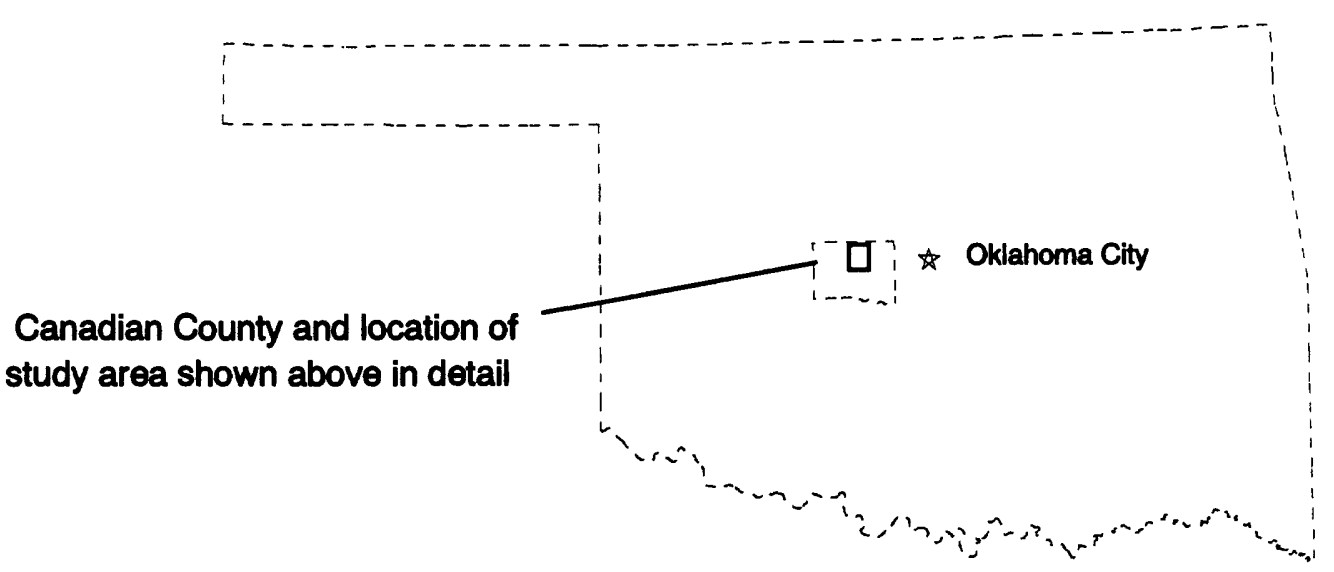

Flgure 1. Location of study area, North Canadian River and the Concho Reserve in Canadian County, Oklahoma. 
tion. A ground-water sample was analyzed for compliance with the primary drinking-water standards set by the U.S. Environmental Protection Agency (1994) and the Oklahoma State Department of Environmental Quality (1992). The water-quality data are given in tables and include field-measured constituents, bacteria counts, and concentrations of the major ions, nutrients, trace elements, radionuclides, and organic compounds.

\section{Acknowledgments}

The author would like to thank Melvin Roman Nose and Robert Wilson of the Cheyenne and Arapaho Tribes of Oklahoma for their help and cooperation. The cooperation of Tom Brothers of the Tribal Farm and Ranch Department, who provided access to tribal land and information, is greatly appreciated.

\section{DESCRIPTION OF STUDY AREA.}

The oldest of three geologic units exposed within the Reserve is the bedrock of the El Reno Group (Pu, fig. 2). The El Reno Group, generally referred to as redbeds, underlies the alluvium and terrace and consists of undifferentiated reddish-brown silty shales with alternating layers of fine-grained sandstone and evaporites (Bingham and Moore, 1975). The terrace (Qt, fig. 2) consists of older alluvial deposits from the North Canadian River and is found along the east-west topographic divide within the Reserve. The lithology of the alluvium and terrace is similar, both are unconsolidated and consist of interfingering lenses of clay, silt, and sand with occasional beds of gravel. The contact between the alluvium and terrace at land surface is located about where the slope changes from low on the alluvium to high on the terrace.

Ground-water supplies from the terrace and El Reno Group bedrock are limited. Ground water from the terrace is of good quality, having total dissolved solids less than $\mathbf{5 0 0}$ milligrams per liter, but the thickness of saturated terrace is limited and the small well yields are sufficient only for domestic supply (Bergman and Savoca, 1993). The bedrock yields small quantities of highly mineralized ground water that is unsuitable for human consumption (Bergman and Savoca,1993).
The alluvium is the youngest deposit of the North Canadian River (Qal, fig. 2). These flat lying sediments form a band in the study area 2 miles long and about 0.5 mile wide along the southern edge of the Reserve. The alluvium provides ground water for most of the municipal, industrial, and irrigation needs in the surrounding area. Water quality is generally poor, with total dissolved solids exceeding 1,000 milligrams per liter (Bergman and Savoca, 1993).

\section{METHODS OF STUDY}

A seismic-refraction survey of the alluvium along the southern edge of the Reserve was done in July and August 1993 to map the variable thickness of the alluvial deposits. A total of 24 discontinuous lines, averaging 150 feet long, were shot at locations shown on figure 3. The eastern one-third of the study area was not surveyed because of saturated ground conditions and poor accessibility.

Six test wells were drilled to bedrock and completed in the alluvium (fig. 3). Water levels, field water-quality constituents, and nitrate concentrations were measured in ground water. Water levels were measured in February and May 1994 to determine the direction of ground-water movement. The chemical constituents of one ground-water sample were analyzed to determine if the water complies with drinking-water standards. A natural-gamma ray $\log$ was run in February 1994 in each test hole to differentiate clay layers from the more permeable sediments.

\section{Selsmlc-Refractlon Survey}

The field equipment consisted of a 12-channel signal-enhancing seismograph with 12 geophones arranged on a seismic cable that averaged 150 feet long. There were four separate shots fired on each line, two forward and two reverse. The energy source was 500-grain, 8-gauge shotgun shells sealed inside plastic capsules that were buried at depths of 1.4 to 3.5 feet and fired electronically with each shot averaging $1,500-2,000$ grains.

The seismic layers identified were the unsaturated and saturated alluvium and the bedrock. Seismic velocities for the unsaturated alluvium and overlying soils ranged from 801 to 1,565 feet per second and averaged 1,069 feet per second. Seismic velocities for 


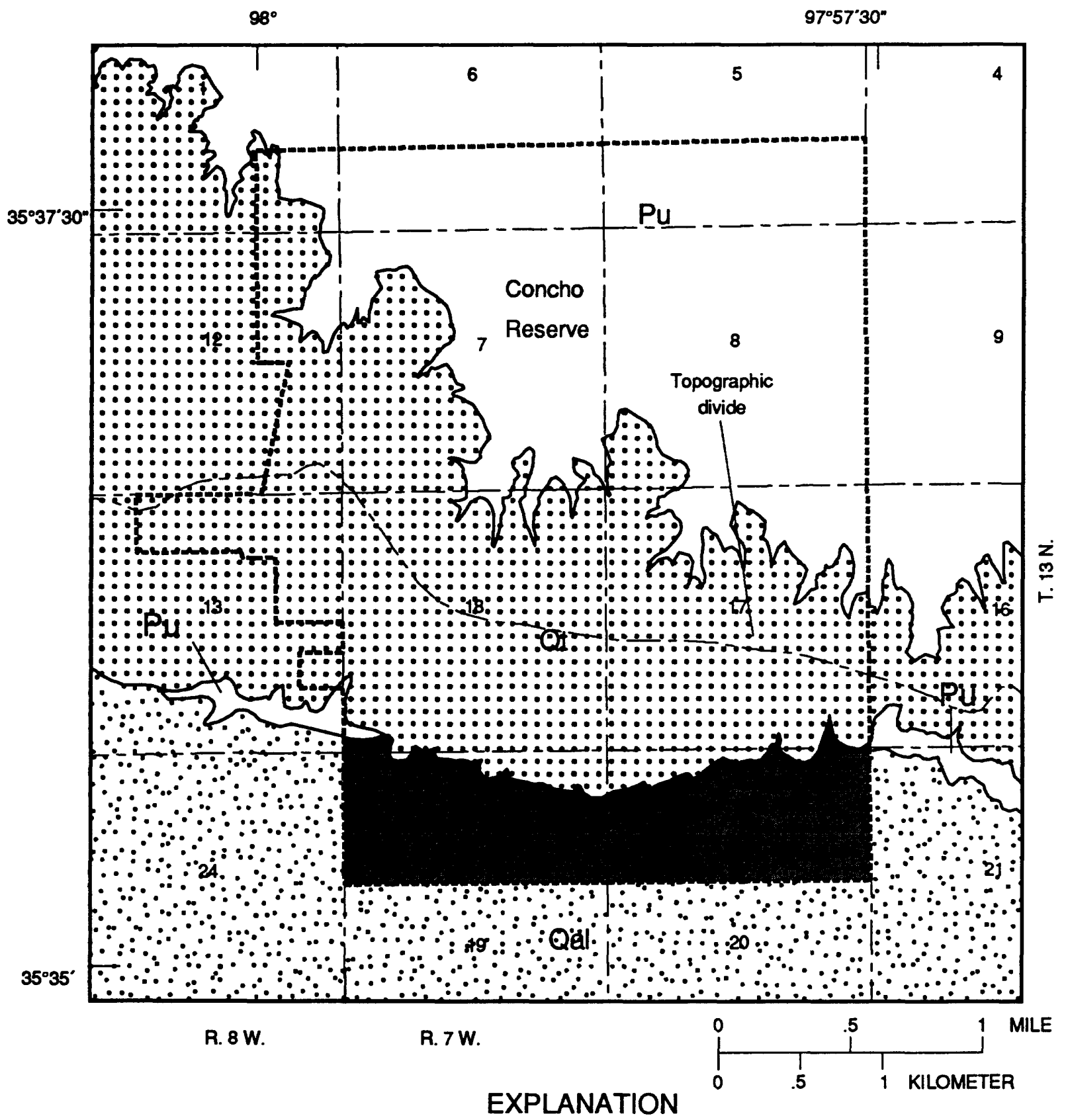
Qal $: \because:$ Alluvium. Unconsolidated clay, silt,
Qt $[: \because: 9$ Terrace deposits. Unconsolidated clay, silt,
PU $\square\left[\begin{array}{l}\text { Undifferentiated Permian rocks of the El Reno Group. } \\ \text { Reddish-brown shale, siltstone, and fine-grained } \\ \text { sandstone, with thin layers of gypsum and dolomite. }\end{array}\right.$

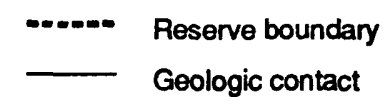
Area of investigation

Figure 2. Geologic units and area of investigation within the Concho Reserve, Canadian County, Oklahoma (Bingham and Moore, 1975). 
'N $\varepsilon\llcorner\perp$

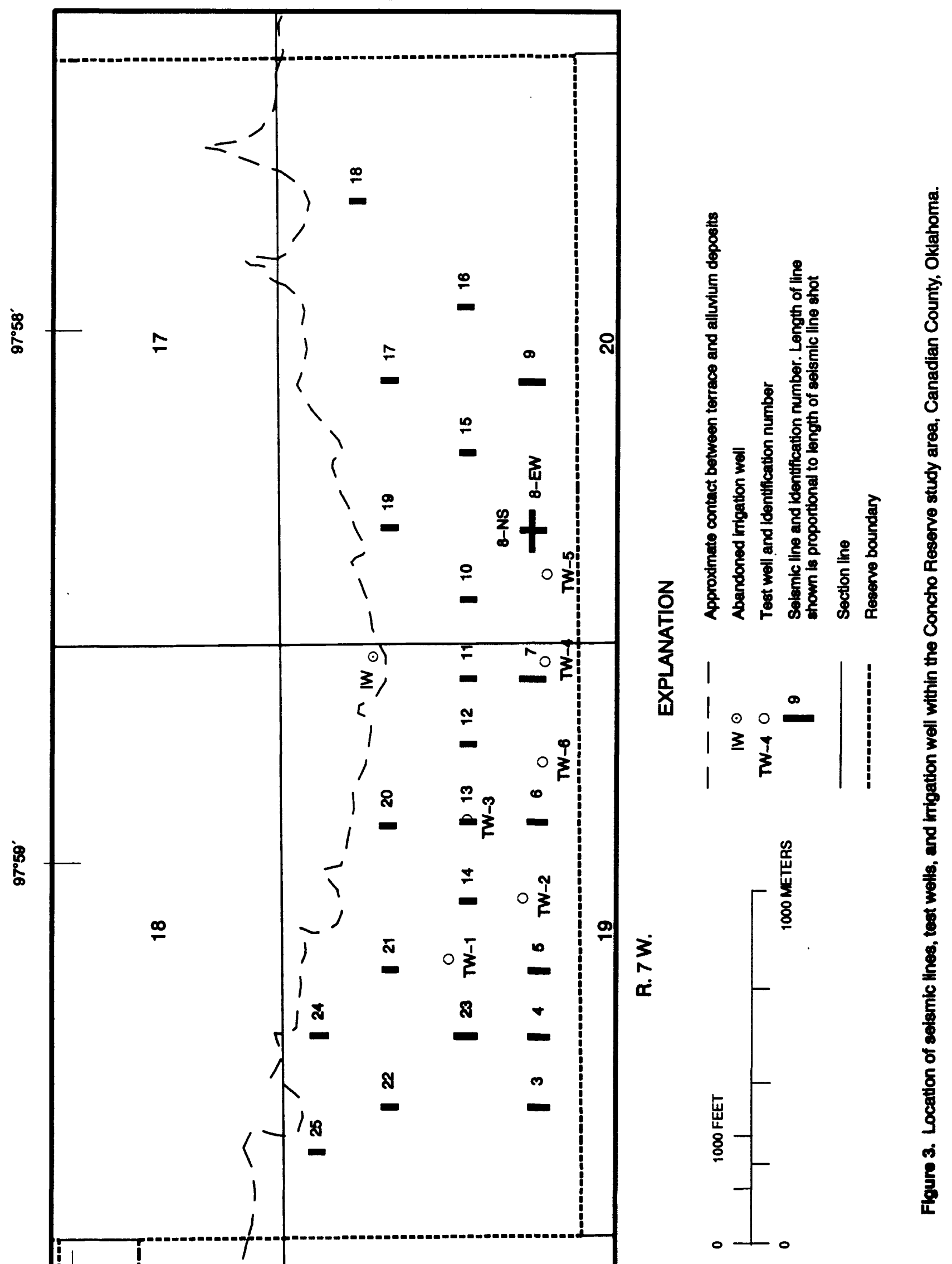


the saturated alluvium ranged from 3,164 to 5,779 feet per second and averaged 5,103 feet per second. The top of the saturated alluvium was determined by the large contrast in seismic velocity to the overlying unsaturated alluvium. The bedrock seismic velocities ranged from 6,556 to 12,465 feet per second, and averaged 8,038 feet per second (table 1). The wide range in bedrock velocities within the study area may be a result of different degrees of weathering of the bedrock surface or the result of variation in lithology (Haeni, 1988). In areas where bedrock velocities were low the determination of depth to bedrock was hindered because of insufficient velocity contrast to the overlying saturated alluvium.

The depths to saturated alluvium and bedrock were interpreted using a three-layer model and the computer-modeling program SIPT23. SIPT23 is based on the delay-time technique developed by Barthelmes (1946), and further modified and developed by Pakiser and Black (1957), Scott (1977a, 1977b), and Scott and others (1972). Table 1 lists seismic-interpreted depth to saturated alluvium, bedrock altitude, and seismic velocities of the three seismic layers.

\section{Test Wells and Water-Quality Analysis}

Six test wells (TW 1-6), ranging from 41.0 to 47.5 feet in depth, were augured to bedrock and completed in the alluvium (table 2). An 8-inch diameter hole was augured and 2-inch diameter PVC casing was installed in 5 of the 6 test wells. Four-inch diameter PVC casing was installed in well TW 4 to facilitate ground-water sampling. The bottom 10 feet of each well was screened with a 0.010 -inch PVC screen; the surrounding unconsolidated sediments created a filter pack. Bentonite clay was used to seal the borehole annulus above the natural filter pack.

Prior to sampling the six test wells and an abandoned irrigation well (designated IW), water equal to three times the volume of the borehole was bailed from the well. Ground-water samples were collected from the 6 test wells and the irrigation well and the temperature, specific conductance, and $\mathrm{pH}$ measured in the field using standard U.S. Geological Survey procedures. The concentration of nitrate as nitrogen was measured in the field using an immunoassay method. A ground water sample from TW-4 was analyzed for bacteria. Samples from TW-4 were sent to the U.S. Geological Survey National Water Quality Laboratory for analysis of water-quality properties, major ion and nutrient concentrations, trace-element and radionuclide concentrations, and organic compound concentrations to determine compliance with drinking-water standards set by Oklahoma State Department of Environmental Quality (1992) and the U.S. Environmental Protection Agency (1994).

\section{HYDROGEOLOGY OF THE ALLUVIUM}

Seismic and test-well data indicate the bedrock surface in the study area is incised with an overall southerly slope toward the North Canadian River (fig. 4). The alluvium ranges from 19 to 75 feet thick and averages about 45 feet in the study area (fig. 5). The alluvium is thinnest near the contact with the terrace. Thickness of the alluvium appears related to the surface of the bedrock; sediments are thickest in areas where the bedrock surface has been incised.

Well cuttings and natural gamma-ray logs indicate the alluvium consists of interfingering lenses of clay, silt, and sand. The increase of coarse-grained sand and the decrease of clay and silt with depth indicates that the water-bearing properties of the aquifer within the study area improve with depth. Pebble and gravel beds, 4 to 8 inches thick were detected during drilling at the base of the alluvium in TW-4 and 5 . Figure 6 shows a generalized section of the North Canadian River alluvial aquifer in the study area using natural gamma-ray logs. The trace of the section is shown in figure 5. Natural gamma-ray logs can help identify zones of low and high permeability in the alluvium. Sediments that contain clay may have low permeability and can be identified on the gamma-ray curves by higher counts per second because of the naturally occurring radioactive elements that compose clay particles. Sediments that may have higher permeabilities because of the absence of or very small amounts of clay can be identified on the gamma-ray curves by lower counts per second. For this study, 40 counts per second is used to delineate high permeability zones; high permeability zones are indicated on the section where gamma-ray curves are less than $\mathbf{4 0}$ counts per second. The pebble and gravel beds detected during drilling cannot be identified on the gamma-ray logs. 


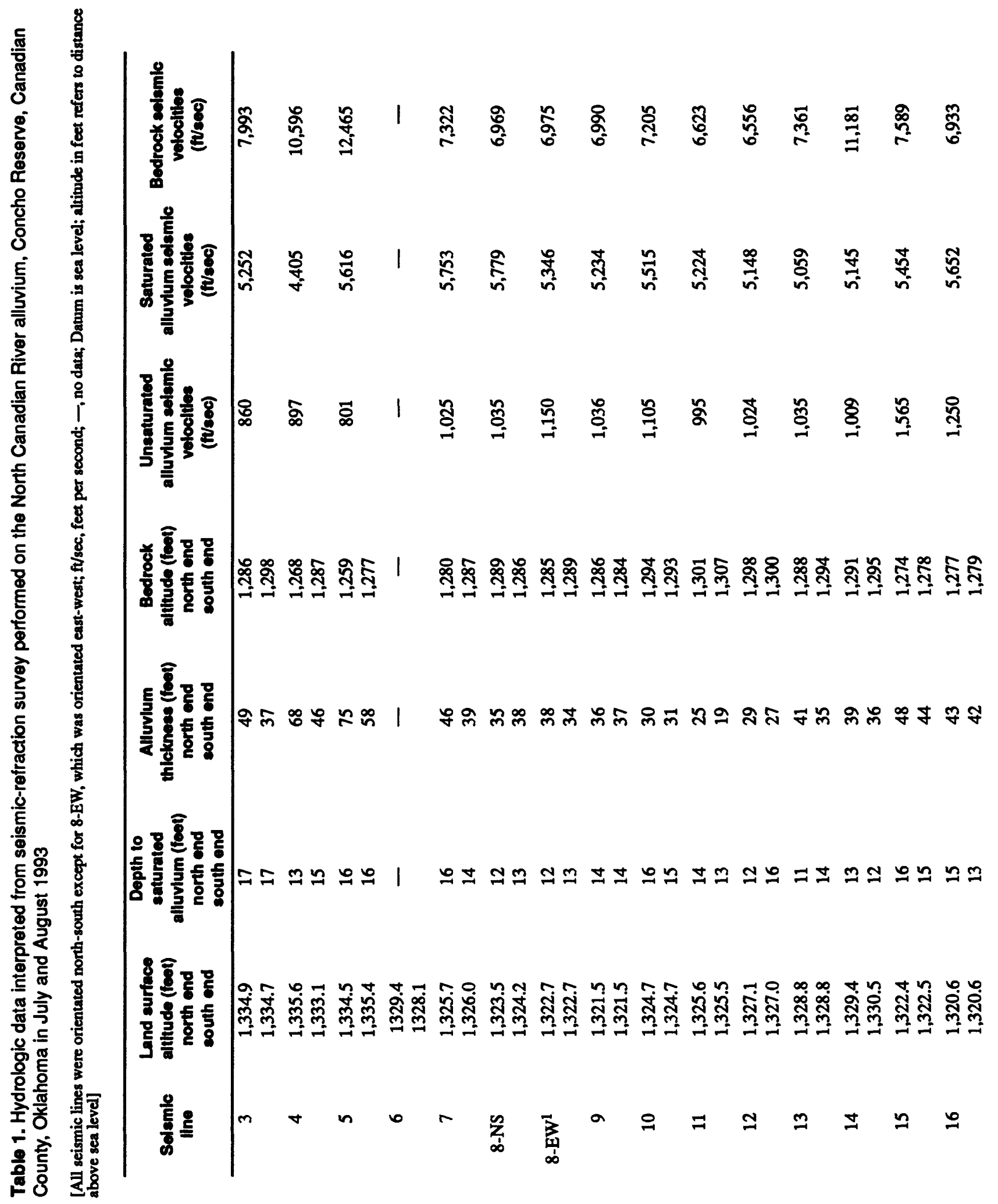




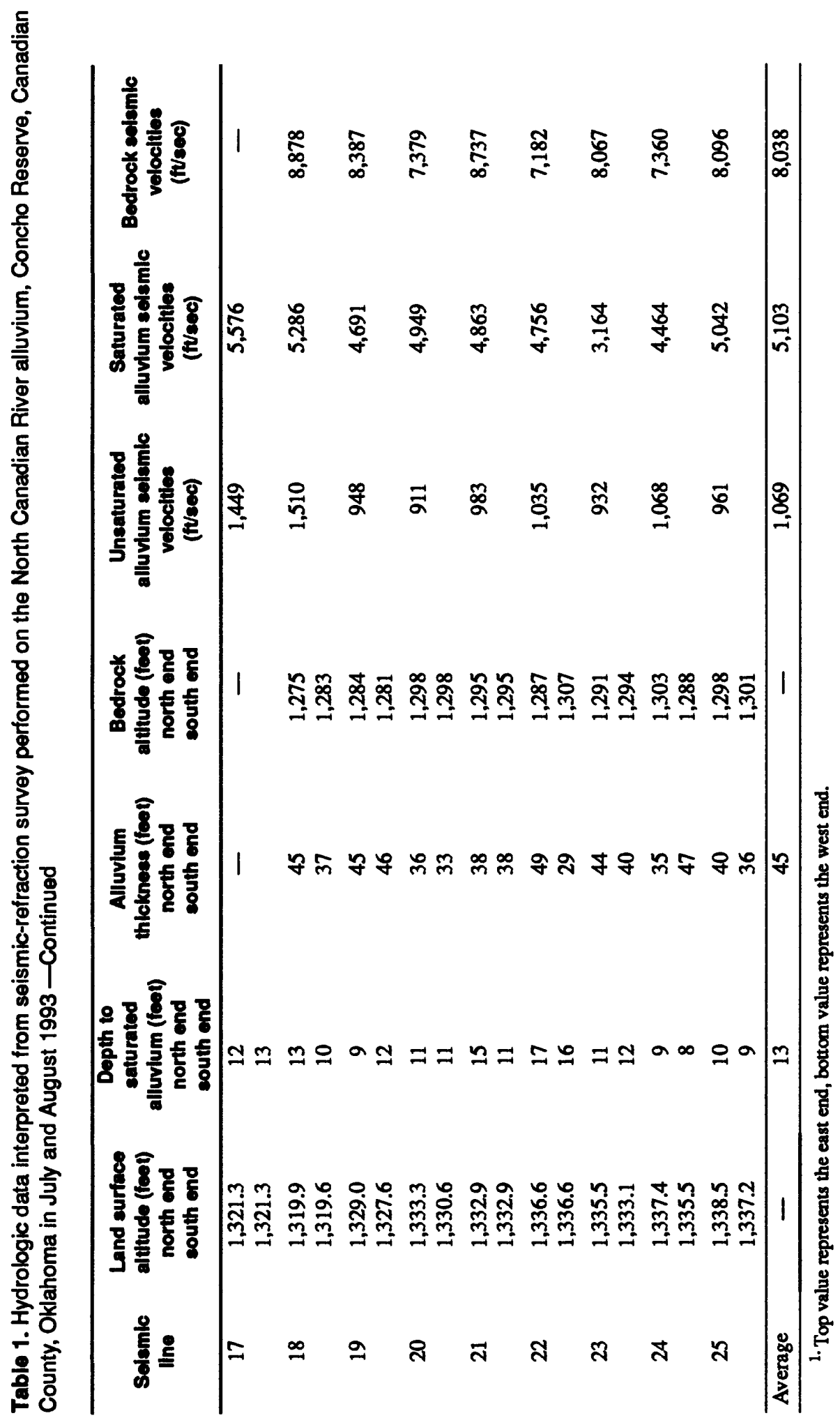




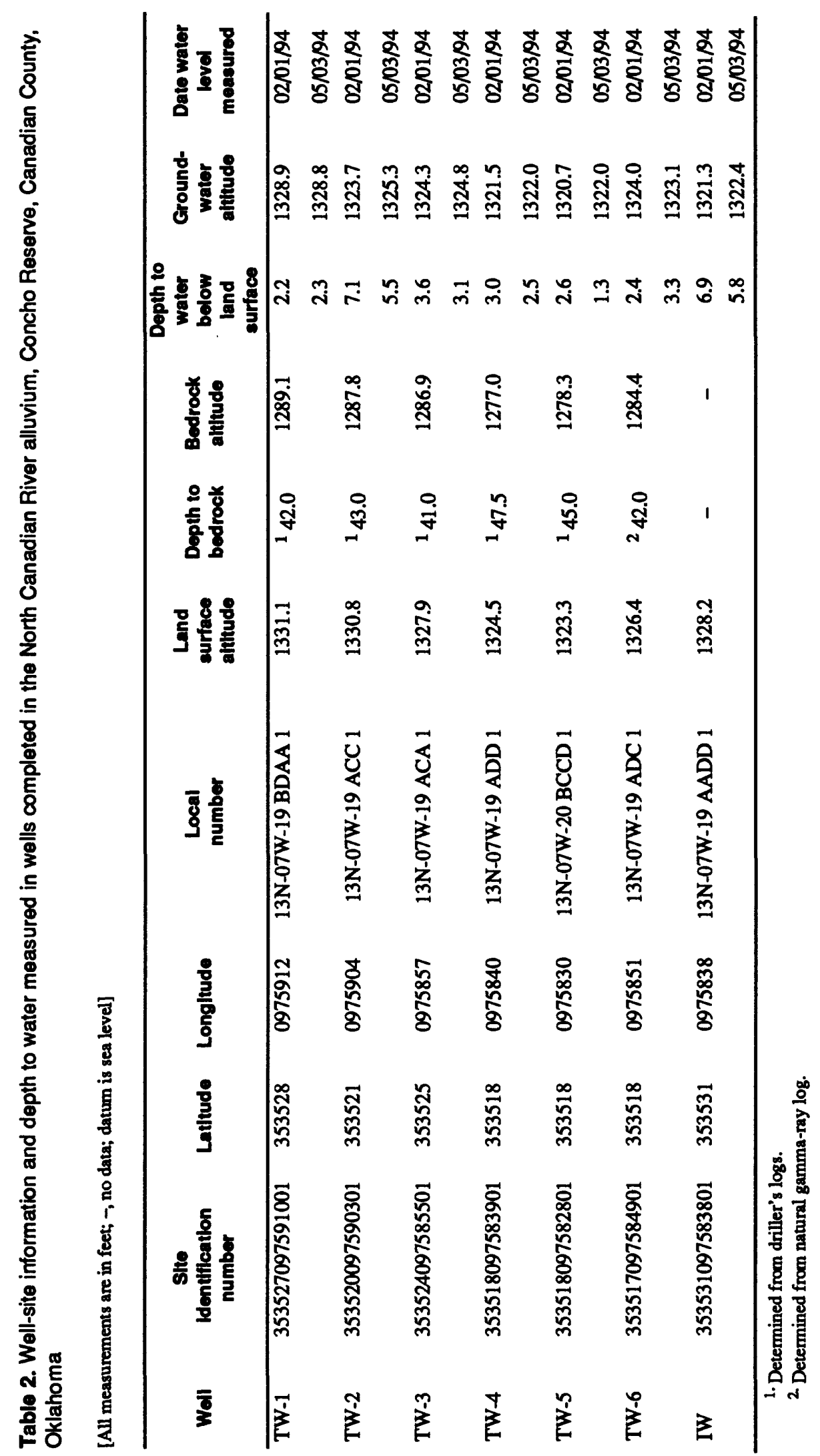




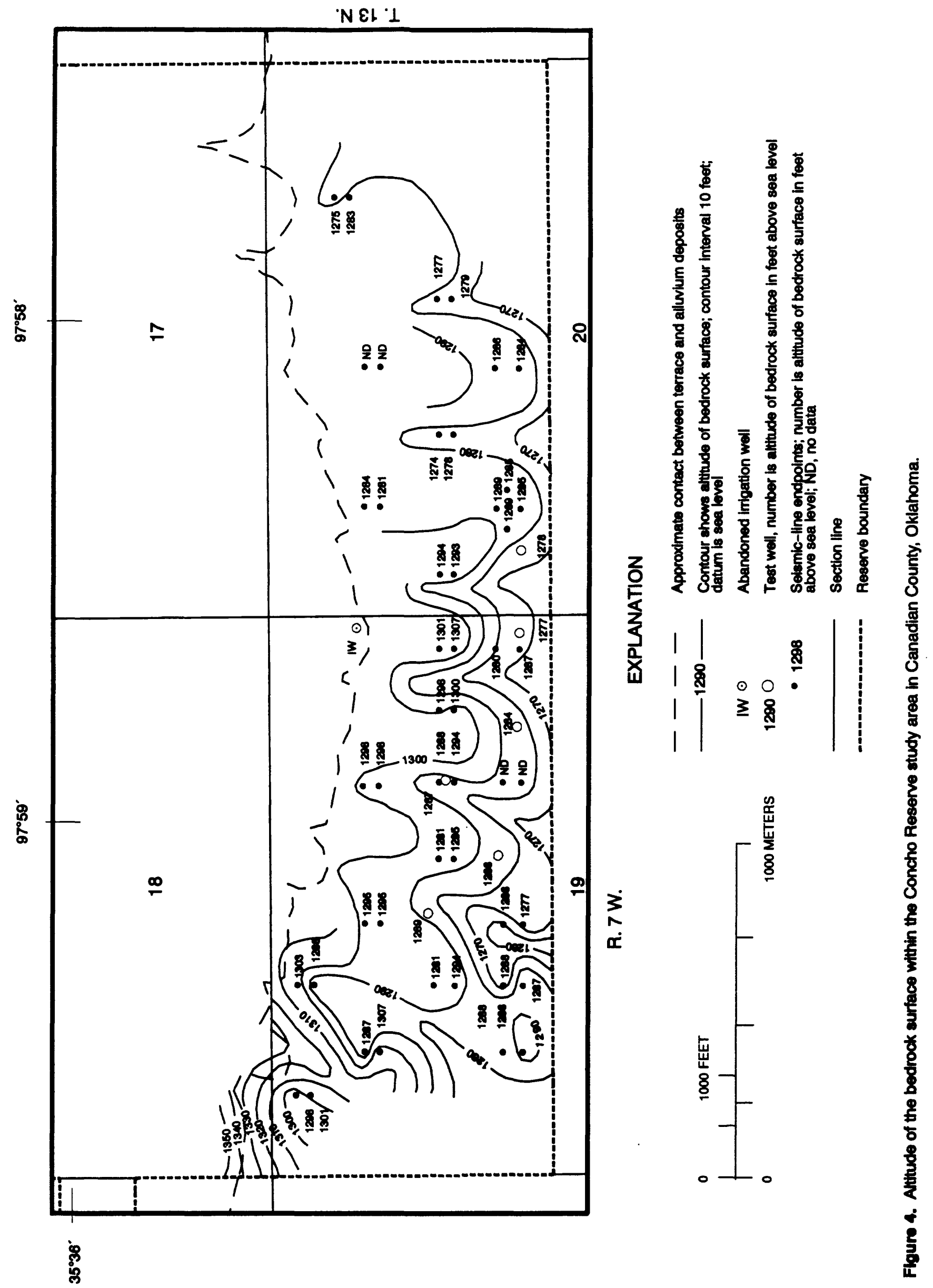




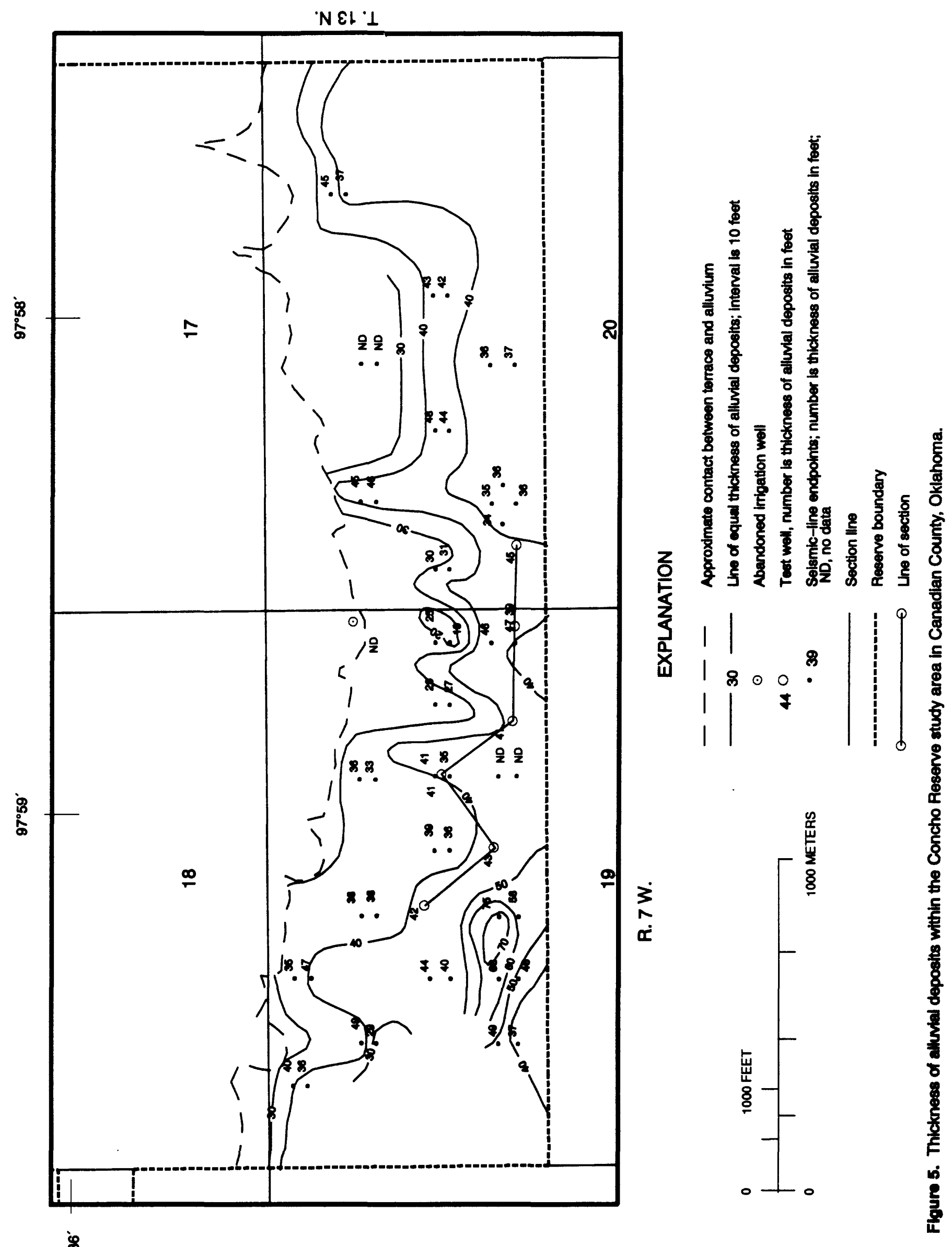


A clay layer in the upper parts of the alluvial aquifer was detected during drilling. The clay layer is indicated by shading on the section in figure 6 where gamma-ray curves exceed 70 counts per second. Gamma-ray curves also exceed 70 counts per second near land surface where clayey soils are present. Soils are not shaded on the section except in TW-6. The thickness of the clay layer ranges from 1.8 to 9.3 feet in the six test wells. The continuity of the clay layer in the study area is unknown, but where it is present it may delay the infiltration of potentially contaminated water from land surface.

Ground water in test wells averaged 3 and 4 feet below land surface during February and May 1994 dry and wet months, respectively. The top of the saturated alluvium in July and August 1993 was interpreted from seismic data and averaged 13 feet below land surface. Water level measurements in test wells during February 1994 and the average depth to saturated alluvium as interpreted from seismic data are shown on the section in figure 6. An aquifer test was not performed and would be the only method of determining whether the difference in water levels measured and water levels interpreted from the seismic data are a result of confined conditions.

A water-table elevation map of the North Canadian River alluvium in Canadian County by Mogg, Schoff, and Reed, (1960, plate 2) indicates ground water movement is in the same general direction as the river, from the northwest to the southeast at about 5 feet per mile. Measurements in test wells, indicate the gradient and direction of ground water movement is not uniform (fig. 7). The gradient between TW-3, 4, 5, and 6 is about 8 feet per mile moving in an easterly to southeasterly direction. The gradient is considerably steeper between TW-1 and 2, at about 31 feet per mile with the direction of flow to the south southeast.

The clay layer may contribute to the ponding of surface water at several locations within the study area. The ponding occurs primarily during the spring when precipitation is greatest. Areas affected include drainage depressions in the northwestem and northeastern quarters of sections 19 and 20 , respectively, and a low-lying area in the center of the study area. Water also ponds in borrow ditches along Reformatory Road on the westem boundary and along U.S. Highway 81 on the eastem boundary of the Reserve (fig. 8). The land surface slopes east-southeasterly at about 10 feet per mile; accordingly, surface water moves in the same direction. U.S. Highway 81 appears to obstruct the surface-water runoff flowing in a southeasterly direction.

\section{WATER QUALITY}

The specific conductance measurement was used to estimate the total dissolved solids in ground water, as most of the dissolved constituents in water are present in ionic form (Freeze and Cherry, 1979, p. 84). Water quality generally deteriorates as the concentration of dissolved minerals in water increases. Specific conductance measurements indicate the water quality in the study area improves - total dissolved solids decrease-in a northerly direction towards the terrace. The specific conductance measured at well IW, located near the contact between the terrace and alluvium, was 660 microsiemens per centimeter in contrast to 1,140 microsiemens per centimeter at well TW-4 located at the southem edge of the study area (table 3). This gradational improvement in water quality may be the result of the dilution of ground water in the alluvium by movement of fresher ground water from the terrace.

Specific conductance measured in the field indicated that water quality was areally variable. A ground-water sample from well TW-4 was analyzed for bacteria, major ions, nutrients, trace elements, radionuclides, and organic compounds.

Analyses indicate the sample from well TW-4 meets all primary drinking-water standards set by the Oklahoma State Department of Environmental Quality (1992) and the U.S. Environmental Protection Agency (1994). However, the measured concentrations of iron, manganese, sulfate, and total dissolved solids exceed the secondary maximum contaminant levels set for drinking water (table 4). Ground water sampled from well TW-4 is calcium sulfate bicarbonate type and is considered very hard, with a hardness value of $\mathbf{5 7 0}$ milligrams per liter as calcium carbonate (table 5). Waters with hardness values greater than 150 milligrams per liter are classified as very hard (Freeze and Cherry, 1979, p. 387). 


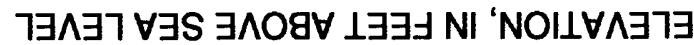

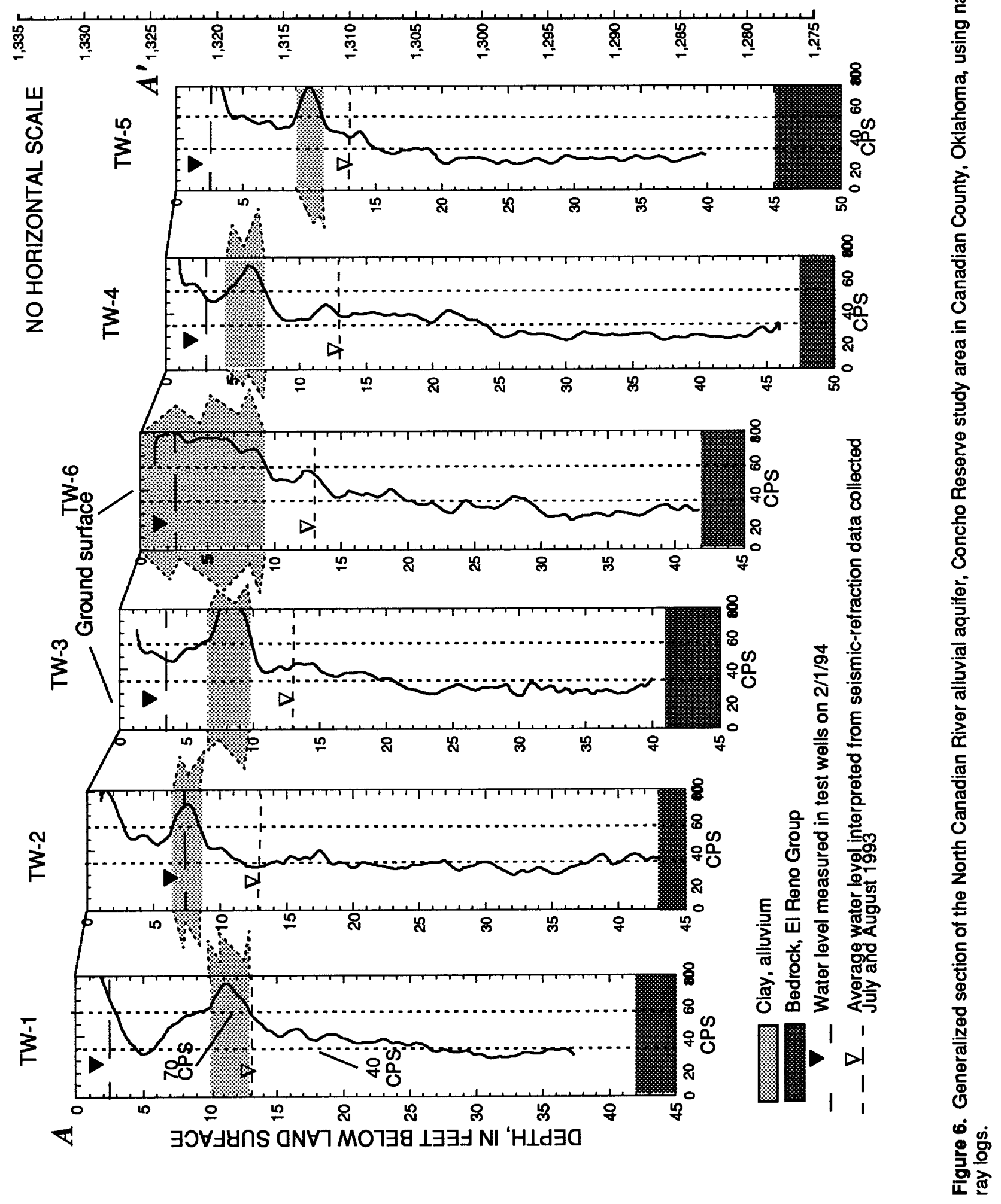




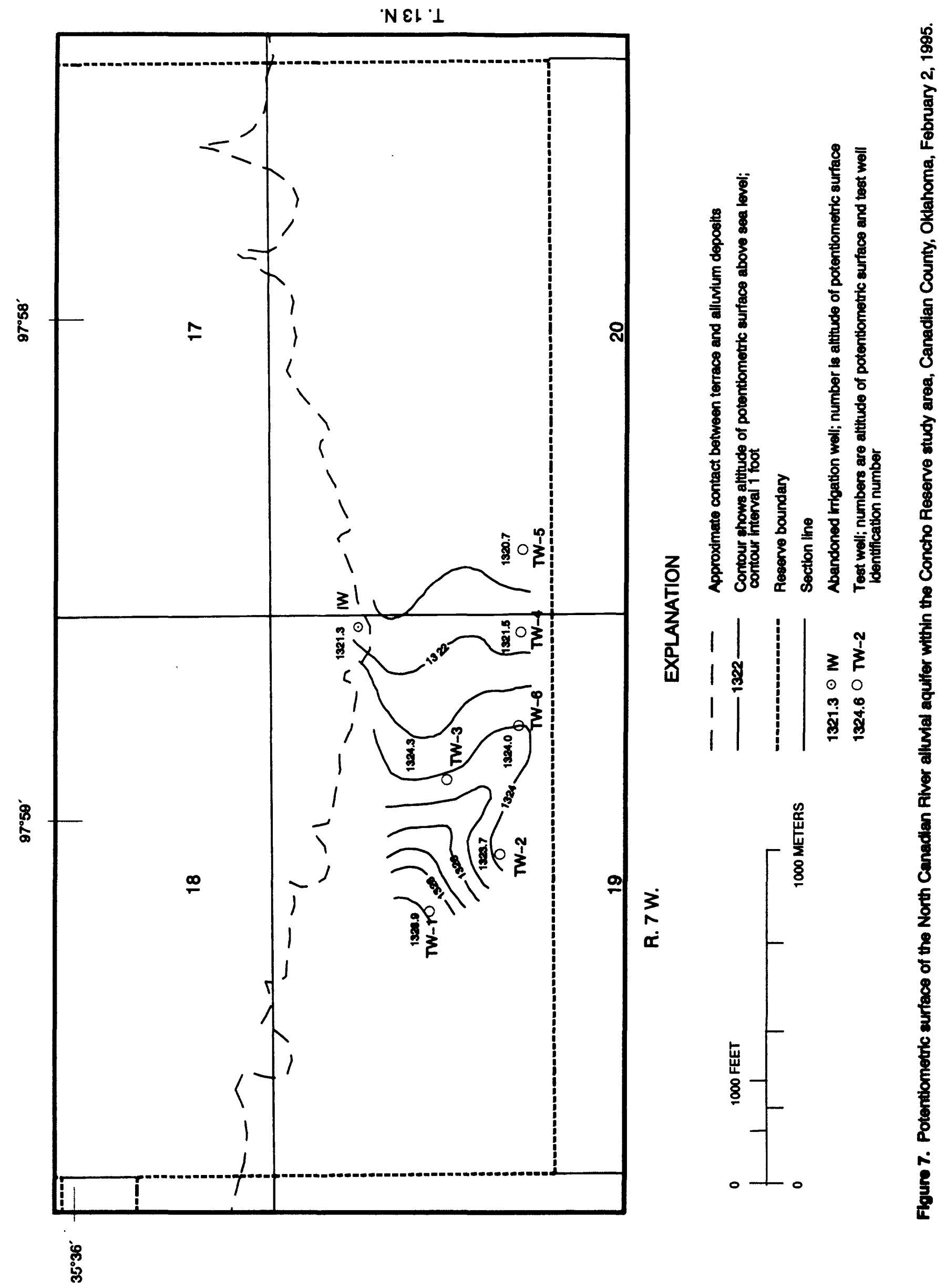




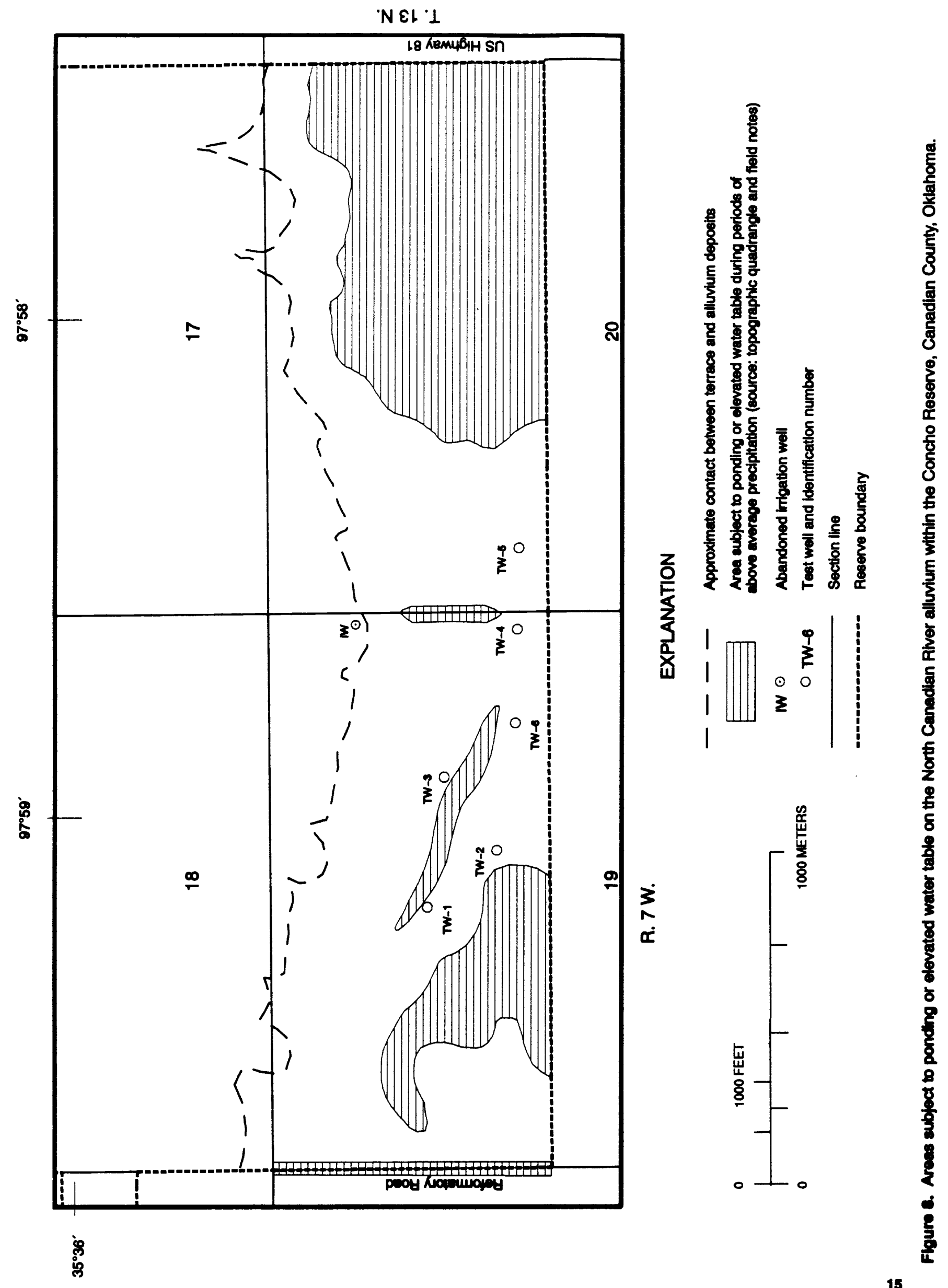


Table 3. Field water-quality measurements collected February 1, 1994, in wells completed in the North Canadian River alluvium, Concho Reserve, Canadian County, Oklahoma

[ ${ }^{\circ} \mathrm{C}$, degrees Celsius; $\mu \mathrm{S} / \mathrm{cm}$, microsiemens per centimeter, $\mathrm{mg} / \mathrm{L}$, milligrams per liter, $<$, less than; —, no data]

\begin{tabular}{|c|c|c|c|c|c|c|c|}
\hline Weil & $\begin{array}{c}\text { Specific } \\
\text { conductance } \\
(\mu \mathrm{s} / \mathrm{cm} \\
\text { at } 25^{\circ} \mathrm{C} \text { ) }\end{array}$ & $\begin{array}{c}\text { pH } \\
\text { (standard } \\
\text { units) }\end{array}$ & $\begin{array}{c}\text { Temperature } \\
\left({ }^{\circ} \mathrm{C}\right)\end{array}$ & $\begin{array}{l}\text { Dissoived } \\
\text { oxygen } \\
\text { (mg/L) }\end{array}$ & $\begin{array}{c}\text { Bicarbonate } \\
\text { as } \mathrm{CaCO}_{3} \\
(\mathrm{mg} / \mathrm{l})\end{array}$ & $\begin{array}{c}\text { Alkallnity } \\
\text { (mg/L) }\end{array}$ & $\begin{array}{c}\text { Nitrate as } \\
\text { nitrogen' } \\
\text { (mg/L) }\end{array}$ \\
\hline TW-1 & 914 & 7.2 & 15.0 & - & - & - & $<1$ \\
\hline TW-2 & 1,164 & 7.2 & 15.0 & - & - & - & $<1$ \\
\hline TW-3 & 992 & 7.3 & 15.0 & - & - & - & $<1$ \\
\hline TW-4 & 1,140 & 7.3 & 15.0 & 2.0 & 500 & 410 & $<1$ \\
\hline TW-5 & 1,170 & 7.2 & 15.0 & - & - & - & $<1$ \\
\hline TW-6 & 1,161 & 7.2 & 15.0 & - & - & - & $<1$ \\
\hline IW & 660 & 7.1 & 15.0 & - & - & - & $<1$ \\
\hline
\end{tabular}

\footnotetext{
${ }^{1}$ Nitrate as nitrogen concentrations were measured using an immunoassay method.
}

Table 4. Measured concentrations of constituents exceeding the secondary maximum contaminant levels set for drinking water by the U.S. Environmental Protection Agency (1994) and the Oklahoma State Department of Environmental Quality (1992) in a ground-water sample collected February 1, 1994, from test well TW-4 completed in the North Canadian River alluvium, Concho Reserve, Canadian County, Oklahoma

$[\mu \mathrm{g} / \mathrm{L}$, micrograms per liter, $\mathrm{mg} / \mathrm{L}$, milligrams per liter]

\begin{tabular}{lccc}
\hline \multicolumn{1}{c}{ Constituent name } & Units & Value & $\begin{array}{c}\text { Secondary maximum } \\
\text { contaminant level }\end{array}$ \\
\hline Iron, dissolved & $\mu \mathrm{g} / \mathrm{L}$ as Fe & 770 & 300 \\
Manganese, dissolved & $\mu \mathrm{g} / \mathrm{L}$ as $\mathrm{Mn}$ & 230 & 50 \\
Sulfate, dissolved & $\mathrm{mg} / \mathrm{L}$ as SO & 250 \\
Dissolved solids (TDS), sum & $\mathrm{mg} / \mathrm{L}$ & 380 & 500 \\
\hline
\end{tabular}


As reported by Bergman and Savoca (1993), potential sources of ground-water contamination to the alluvial aquifer on the Concho Reserve are nitrogen from stock animals and fertilizer (ammonium nitrate) and the pesticides methyl parathion and Glean (chlorosulfuron). Nitrate as nitrogen concentrations, measured in the field by an immunoassay method, were well below maximum contaminant levels of 10.0 milligrams per liter (table 3). Similarly, laboratory measurements of nitrite and nitrite plus nitrate were below maximum contaminant levels of 1.0 and 10.0 milligrams per liter as nitrogen, respectively, in a water sample from well TW-4 (table 5). Methyl parathion was not detected at a reporting level of 0.01 micrograms per liter (table 5). Ground water was not analyzed for Glean because no U.S. Geological Survey laboratory method was available at the time of the study. No standards have been set for methyl parathion and Glean in drinking water at the time this report was written (1997).

\section{SUMMARY}

This study was undertaken to collect and analyze data to describe the hydrogeology and groundwater quality of the North Canadian River alluvium.

The alluvium forms a band about 2 miles long and 0.5 mile wide along the southern edge of the Concho Reserve. The alluvium ranges from 19 to 75 feet thick and averages about 45 feet in the study area. Well cuttings and natural gamma-ray logs indicate the alluvium consists of interfingering lenses of clay, silt, and sand. The increase of coarse-grained sand and the decrease of clay and silt with depth indicates that the water-bearing properties of the aquifer within the study area improve with depth. A clay layer in the upper part of the aquifer may be partially responsible for surface-water ponding in low areas after above normal precipitation and may delay the infiltration of potentially contaminated water from land surface.

Specific conductance measurements indicate the ground-water quality improves in a northern direction towards the terrace. Ground water from well TW-4 meets all of the primary drinking-water standards. Iron, manganese, sulfate and total dissolved solids exceed the secondary maximum contaminant levels set for drinking water. The ground water is calcium sulfate bicarbonate type and is considered very hard, with a hardness of $\mathbf{5 7 0}$ milligrams per liter as calcium carbonate. Nitrogen was detected at concentrations significantly below maximum concentration levels and methyl parathion was not detected at reporting level of less than 0.01 micrograms per liter.

\section{REFERENCES CITED}

Barthelmes, AJ., 1946, Application of continuous profiling to refraction shooting: Geophysics, v. 11, no. 1, p. 24-42.

Bergman, D.L., and Savoca, M.E., 1993, Land-use and ground-water data, Cheyenne-Arapaho Tribes, Concho Reserve, Canadian County, Oklahoma: U. S. Geological Survey Open-File Report 93-110, 2 plates.

Bingham, R.H., and Moore, R.L., 1975, Reconnaissance of the water resources of the Oklahoma City quadrangle, central Oklahoma: Oklahoma Geological Survey Hydrologic Atlas 4, 4 sheets scale 1:250,000.

Freeze, R. A., and Cherry, J.A., 1979, Groundwater: Englewood Cliffs, N.J., Prentice-Hall, p. 84, 387.

Haeni, F.P., 1988, Application of seismic-refraction techniques to hydrologic studies: U.S. Geological Survey Techniques of Water-Resources Investigations, book 2 , chap. D2, $86 \mathrm{p}$.

Mogg, J.L., Schoff, S.L., and Reed, E.W., 1960, Ground water resources of Canadian County, Oklahoma: Oklahoma Geological Survey Bulletin 87, 112 p.

Oklahoma State Department of Environmental Quality, 1992, Public water supply regulations, Section 310 Chapter 330-1-3.

Pakiser, L.C., and Black, R.A., 1957, Exploring for ancient channels with the refraction seismograph: Geophysics, v. 22 , no. 1, p. 32-47.

Scott, J.H., 1977a, SIPB.-A seismic inverse modeling program for batch computer systems: U.S. Geological Survey Open-File Report 77-366, 40 p.

1977b, SIPT.-A seismic refraction inverse modeling program for timeshare terminal computer systems: U.S. Geological Survey Open-File Report 77-365, 35 p.

Scott, J.H., Tibbetts, B.L., and Burdick, R.G., 1972, Computer analysis of seismic refraction data: U. S. Bureau of Mines, Report of Investigations 7595, 95 p.

U.S. Environmental Protection Agency, 1994, Maximum and secondary maximum contaminant levels (National primary drinking-water regulations): U.S. Code of Federal Regulations, Title 40, Parts 141-143, p. 658-837. 
Table 5 
Table 5. Laboratory measured water-quality properties, bacteria counts, major ion and nutrient concentrations, trace-element and radionuclide concentrations, and organic compound concentrations in a ground-water sample collected February 1. 1994, from test well TW-4 completed in the North Canadian River alluvium, Concho Reserve, Canadian County, Oklahoma

$\left[{ }^{\circ} \mathrm{C}\right.$, degrees Celsius; $\mathrm{mg} / \mathrm{L}$, milligrams per liter, NTU, nephelometric turbidity units; <, measured concentration is less than the reporting level; \pm , plus or minus; $\mu$, micrograms; $\mu \mathrm{g} / \mathrm{L}$, micrograms per liter, $\mathrm{pCi} / \mathrm{L}$, picoCuries per liter]

\begin{tabular}{|c|c|c|}
\hline Consiltuent name & Units & Value \\
\hline \multicolumn{3}{|c|}{ Water-quality properties } \\
\hline Specific conductance, lab & microsiemens $/ \mathrm{cm}$ & 1,220 \\
\hline pH, whole & Standard units & 7.2 \\
\hline Turbidity & NTU & 21 \\
\hline Hardness, total & $\mathrm{mg} / \mathrm{L}$ as $\mathrm{CaCO}_{3}$ & 570 \\
\hline Alkalinity, lab, fixed end point & $\mathrm{mg} / \mathrm{L}$ as $\mathrm{CaCO}_{3}$ & 277 \\
\hline \multicolumn{3}{|c|}{ Bacteria counts } \\
\hline Fecal coliform & count & 0 \\
\hline Fecal streptococci & count & 0 \\
\hline \multicolumn{3}{|c|}{ Major ion and nutrient concentrations } \\
\hline Dissolved solids (TDS), sum & $\mathrm{mg} / \mathrm{L}$ & 852 \\
\hline $\begin{array}{l}\text { Dissolved solids (TDS), residue on evapora- } \\
\text { tion at } 180^{\circ} \mathrm{C}\end{array}$ & $\mathrm{mg} / \mathrm{L}$ & 898 \\
\hline Calcium, dissolved & $\mathrm{mg} / \mathrm{L}$ as $\mathrm{Ca}$ & 160 \\
\hline Magnesium, dissolved & $\mathrm{mg} / \mathrm{L}$ as $\mathrm{Mg}$ & 40 \\
\hline Sodium, dissolved & $\mathrm{mg} / \mathrm{L}$ as $\mathrm{Na}$ & 56 \\
\hline Sodium, percent & Percent & 18 \\
\hline Sodium adsorption ratio & Ratio & 1 \\
\hline Potassium, dissolved & $\mathrm{mg} / \mathrm{L}$ as $\mathrm{K}$ & 2.2 \\
\hline Sulfate, dissolved & $\mathrm{mg} / \mathrm{L}$ as $\mathrm{SO}_{4}$ & 380 \\
\hline Chloride, dissolved & $\mathrm{mg} / \mathrm{L}$ as $\mathrm{Cl}$ & 22 \\
\hline Fluoride, dissolved & $\mathrm{mg} / \mathrm{L}$ as $\mathrm{F}$ & 0.60 \\
\hline Bromide, dissolved & $\mathrm{mg} / \mathrm{L}$ as $\mathrm{Br}$ & 0.14 \\
\hline Silica, dissolved & $\mathrm{mg} / \mathrm{L}$ as $\mathrm{SiO}_{2}$ & 22 \\
\hline Nitrite as nitrogen, dissolved & $\mathrm{mg} / \mathrm{L}$ as $\mathrm{N}$ & 0.004 \\
\hline Nitrate as nitrogen, dissolved & $\mathrm{mg} / \mathrm{L}$ as $\mathrm{N}$ & 0.001 \\
\hline Nitrite plus nitrate, dissolved & $\mathrm{mg} / \mathrm{L}$ as $\mathrm{N}$ & 0.005 \\
\hline Nitrogen ammonia, dissolved & $\mathrm{mg} / \mathrm{L}$ as $\mathrm{N}$ & 0.112 \\
\hline Phosphorus, orthophosphate, dissolved & $\mathrm{mg} / \mathrm{L}$ as $\mathrm{P}$ & 0.019 \\
\hline
\end{tabular}

Trace-element and radionuclide concentrations

Aluminum, dissolved

Antimony, dissolved

Arsenic, dissolved

Barium, dissolved

Beryllium, dissolved

Cadmium, dissolved

Chromium, dissolved

Cobalt, dissolved

Copper, dissolved

Iron, dissolved

$\begin{array}{lc}\mu \mathrm{g} / \mathrm{L} \text { as } \mathrm{Al} & <10 \\ \mu \mathrm{g} / \mathrm{L} \text { as } \mathrm{Sb} & <1 \\ \mu \mathrm{g} / \mathrm{L} \text { as } \mathrm{As} & 3 \\ \mathrm{mg} / \mathrm{L} \text { as } \mathrm{Ba} & 58 \\ \mathrm{mg} / \mathrm{L} \text { as } \mathrm{Be} & <0.5 \\ \mu \mathrm{g} / \mathrm{L} \text { as } \mathrm{Cd} & 2.0 \\ \mu \mathrm{g} / \mathrm{L} \text { as } \mathrm{Cr} & <5 \\ \mu \mathrm{g} / \mathrm{L} \text { as } \mathrm{Co} & <3 \\ \mu \mathrm{g} / \mathrm{L} \text { as } \mathrm{Cu} & <10 \\ \mu \mathrm{g} / \mathrm{L} \text { as } \mathrm{Fe} & 770\end{array}$


Table 5. Laboratory measured water-quality properties, bacteria counts, major ion and nutrient concentrations, trace-element and radionuclide concentrations, and organic compound concentrations in a ground-water sample collected February 1, 1994, from test well TW-4 completed in the North Canadian River alluvium, Concho Reserve, Canadian County, Oklahoma - Continued

\begin{tabular}{lcc}
\hline \multicolumn{1}{c}{ Constituent name } & UnIts & Value \\
\hline Lead, dissolved & $\mu \mathrm{g} / \mathrm{L}$ as $\mathrm{Pb}$ & $<10$ \\
Lithium, dissolved & $\mu \mathrm{g} / \mathrm{L}$ as $\mathrm{Li}$ & 32 \\
Manganese, dissolved & $\mu \mathrm{g} / \mathrm{L}$ as $\mathrm{Mn}$ & 230 \\
Mercury, dissolved & $\mu \mathrm{g} / \mathrm{L}$ as $\mathrm{Hg}$ & $<0.1$ \\
Molybdenum, dissolved & $\mu \mathrm{g} / \mathrm{L}$ as $\mathrm{Mo}$ & 10 \\
Nickel, dissolved & $\mu \mathrm{g} / \mathrm{L}$ as $\mathrm{Ni}$ & $<10$ \\
Selenium, dissolved & $\mu \mathrm{g} / \mathrm{L}$ as $\mathrm{Se}$ & $<1$ \\
Silver, dissolved & $\mu \mathrm{g} / \mathrm{L}$ as $\mathrm{Ag}$ & $<1.0$ \\
Strontium, dissolved & $\mu \mathrm{g} / \mathrm{L}$ as $\mathrm{Sr}$ & 1,400 \\
Vanadium, dissolved & $\mu \mathrm{g} / \mathrm{L}$ as $\mathrm{V}$ & $<6$ \\
Zinc, dissolved & $\mu \mathrm{g} / \mathrm{L}$ as $\mathrm{Zn}$ & 8 \\
Uranium, natural, dissolved & $\mu \mathrm{g} / \mathrm{L}$ & $1.3 \pm 1.3$ \\
Radium 226, dissolved, radon method & $\mathrm{pCi} / \mathrm{L}$ & $0.2 \pm 0.04$
\end{tabular}

Organic compound concentrations

Acenaphthene, total

Acenaphthylene, total

Acrolein, total

Acrylonitrile, total

Alachlor, dissolved, recoverable

Aldrin, total

Anthracene, total

Atrazine, dissolved, recoverable

Benfluralin, dissolved $0.7 \mu$ glass fiber, recoverable

1,2-benzanthracene benzo (a) anthracene, total

Benzene, total

Benzidine, total

Benzo (b) fluoranthene, total

Benzo $(k)$ fluoranthene, total

Benzo (a) pyrene, total

1,1,2-benzoperylene, total

$a-B H C$

Bromobenzene, total

Bromochloromethane, total, recoverable

Bromoform, total

4-bromophenylphenylether, total

Butylate, dissolved, recoverable

n-butylbenzene, total, recoverable

sec-butylbenzene, total, recoverable

n-butylbenzylphthalate, total $\mu \mathrm{g}$

$\mu \mathrm{g} / \mathrm{L}$

$\mu \mathrm{g} / \mathrm{L}$

$\mu \mathrm{g} / \mathrm{L}$

$\mu \mathrm{g} / \mathrm{L}$

$\mu \mathrm{g} / \mathrm{L}$

$\mu \mathrm{g} / \mathrm{L}$

$\mu \mathrm{g} / \mathrm{L}$

$\mu \mathrm{g} / \mathrm{L}$

$\mu \mathrm{g} / \mathrm{L}$

$\mu \mathrm{g} / \mathrm{L}$

$\mu \mathrm{g} / \mathrm{L}$

$\mu \mathrm{g} / \mathrm{L}$

$\mu \mathrm{g} / \mathrm{L}$

$\mu \mathrm{g} / \mathrm{L}$

$\mu \mathrm{g} / \mathrm{L}$

$\mu \mathrm{g} / \mathrm{L}$

$\mu \mathrm{g} / \mathrm{L}$

$\mu \mathrm{g} / \mathrm{L}$

$\mu \mathrm{g} / \mathrm{L}$

$\mu \mathrm{g} / \mathrm{L}$

$\mu \mathrm{g} / \mathrm{L}$

$\mu \mathrm{g} / \mathrm{L}$

$\mu \mathrm{g} / \mathrm{L}$

$\mu \mathrm{g} / \mathrm{L}$
$<5.0$

$<5.0$

$<20$

$<20$

$<0.01$

$<0.010$

$<5.0$

$<0.02$

$<0.01$

$<10.0$

$<0.2$

$<40.0$

$<10.0$

$<10.0$

$<10.0$

$<10.0$

$<0.01$

$<0.2$

$<0.20$

$<0.2$

$<5.0$

$<0.01$

$<0.20$

$<0.20$

$<5.0$ 
Table 5. Laboratory measured water-quality properties, bacteria counts, major ion and nutrient concentrations, trace-element and radionuclide concentrations, and organic compound concentrations in a ground-water sample collected February 1, 1994, from test well TW-4 completed in the North Canadian River alluvium, Concho Reserve, Canadian County, Oklahoma - Continued

\begin{tabular}{|c|c|c|}
\hline Constituent name & Unlts & Value \\
\hline $\begin{array}{l}\text { Carbaryl, dissolved } 0.7 \mu \text { glass fiber } \\
\text { recoverable }\end{array}$ & $\mu \mathrm{g} / \mathrm{L}$ & $<0.05$ \\
\hline $\begin{array}{l}\text { Carbofuran, dissolved } 0.7 \mu \text { glass fiber, } \\
\text { recoverable }\end{array}$ & $\mu \mathrm{g} / \mathrm{L}$ & $<0.01$ \\
\hline Carbon tetrachloride, total & $\mu \mathrm{g} / \mathrm{L}$ & $<0.2$ \\
\hline Chlordane, total & $\mu \mathrm{g} / \mathrm{L}$ & $<0.1$ \\
\hline Chlorobenzene, total & $\mu \mathrm{g} / \mathrm{L}$ & $<0.20$ \\
\hline o-chlorobenzene, total, recoverable & $\mu \mathrm{g} / \mathrm{L}$ & $<0.20$ \\
\hline o-chlorobenzene, total, recoverable & $\mu \mathrm{g} / \mathrm{L}$ & $<5.0$ \\
\hline Chlorodibromomethane, total & $\mu \mathrm{g} / \mathrm{L}$ & $<0.2$ \\
\hline Chloroethane, total & $\mu \mathrm{g} / \mathrm{L}$ & $<0.2$ \\
\hline bis (2-chloroethoxy) methane, total & $\mu \mathrm{g} / \mathrm{L}$ & $<5.0$ \\
\hline bis (2-chloroethyl) ether, total & $\mu \mathrm{g} / \mathrm{L}$ & $<5.0$ \\
\hline 2-chloroethylvinylether, total & $\mu \mathrm{g} / \mathrm{L}$ & $<1.0$ \\
\hline Chloroform, total & $\mu \mathrm{g} / \mathrm{L}$ & $<0.2$ \\
\hline bis (2-chloroisopropyl) ether, total & $\mu \mathrm{g} / \mathrm{L}$ & $<5.0$ \\
\hline$p$-chloro-m-cresol, total & $\mu \mathrm{g} / \mathrm{L}$ & $<30.0$ \\
\hline 2-chloronaphthalene, total & $\mu \mathrm{g} / \mathrm{L}$ & $<5.0$ \\
\hline 2-chlorophenol, total & $\mu \mathrm{g} / \mathrm{L}$ & $<5.0$ \\
\hline 4-chlorophenyl phenyl ether, total & $\mu \mathrm{g} / \mathrm{L}$ & $<5.0$ \\
\hline o-chlorotoluene, total & $\mu \mathrm{g} / \mathrm{L}$ & $<0.2$ \\
\hline$p$-chlorotoluene, total, recoverable & $\mu \mathrm{g} / \mathrm{L}$ & $<0.20$ \\
\hline Chlorpyrifos, dissolved & $\mu \mathrm{g} / \mathrm{L}$ & $<0.005$ \\
\hline Chlorpyrifos, total, recoverable & $\mu \mathrm{g} / \mathrm{L}$ & $<0.01$ \\
\hline Chrysene, total & $\mu \mathrm{g} / \mathrm{L}$ & $<10.0$ \\
\hline Cyanazine, dissolved, recoverable & $\mu \mathrm{g} / \mathrm{L}$ & $<0.01$ \\
\hline $\begin{array}{l}\text { DCPA, dissolved } 0.7 \mu \text { glass fiber, } \\
\text { recoverable }\end{array}$ & $\mu \mathrm{g} / \mathrm{L}$ & $<0.004$ \\
\hline DDD, total & $\mathrm{mg} / \mathrm{L}$ & $<0.010$ \\
\hline DDE, total & $\mathrm{mg} / \mathrm{L}$ & $<0.010$ \\
\hline$p, p^{\prime}-\mathrm{DDE}$, dissolved & $\mu \mathrm{g} / \mathrm{L}$ & $<0.01$ \\
\hline DDT, total & $\mathrm{mg} / \mathrm{L}$ & $<0.010$ \\
\hline DEF, total & $\mu \mathrm{g} / \mathrm{L}$ & $<0.01$ \\
\hline Diazinon, dissolved & $\mu \mathrm{g} / \mathrm{L}$ & $<0.01$ \\
\hline Diazinon, total & $\mu \mathrm{g} / \mathrm{L}$ & $<0.01$ \\
\hline 1,2,5,6-dibenzanthracene, total & $\mu \mathrm{g} / \mathrm{L}$ & $<10.0$ \\
\hline Dibromochloropropane, total, recoverable & $\mu \mathrm{g} / \mathrm{L}$ & $<1.0$ \\
\hline 1,2-dibromoethane, total & $\mu \mathrm{g} / \mathrm{L}$ & $<0.2$ \\
\hline Dibromomethane, total, recoverable & $\mu_{g / L}$ & $<0.2$ \\
\hline 1,3-dichlorobenzene, total, recoverable & $\mu \mathrm{g} / \mathrm{L}$ & $<0.20$ \\
\hline 1,4-dichlorobenzene, total, recoverable & $\mu \mathrm{g} / \mathrm{L}$ & $<0.20$ \\
\hline
\end{tabular}


Table 5. Laboratory measured water-quality properties, bacteria counts, major ion and nutrient concentrations, trace-element and radionuclide concentrations, and organic compound concentrations in a ground-water sample collected February 1, 1994, from test well TW-4 completed in the North Canadian River alluvium, Concho Reserve, Canadian County, Oklahoma - Continued

\begin{tabular}{|c|c|c|}
\hline Constituent name & Units & Value \\
\hline 3,3-dichlorobenzidine, total & $\mu \mathrm{g} / \mathrm{L}$ & $<20.0$ \\
\hline Dichlorobromomethane, total & $\mu \mathrm{g} / \mathrm{L}$ & $<0.2$ \\
\hline Dichlorodifluoromethane, total & $\mu \mathrm{g} / \mathrm{L}$ & $<0.2$ \\
\hline 1,1-dichloroethane, total & $\mu \mathrm{g} / \mathrm{L}$ & $<0.2$ \\
\hline 1,2-dichloroethane, total & $\mu \mathrm{g} / \mathrm{L}$ & $<0.2$ \\
\hline cis-1,2-dichloroethene, total & $\mu \mathrm{g} / \mathrm{L}$ & $<0.2$ \\
\hline trans-1,2-dichloroethene, total & $\mu \mathrm{g} / \mathrm{L}$ & $<0.2$ \\
\hline 1,1-dichloroethylene, total & $\mu \mathrm{g} / \mathrm{L}$ & $<0.2$ \\
\hline 2,4-dichlorophenol, total & $\mu \mathrm{g} / \mathrm{L}$ & $<5.0$ \\
\hline 1,2-dichloropropane, total & $\mu \mathrm{g} / \mathrm{L}$ & $<0.2$ \\
\hline 1,3-dichloropropane, total & $\mu \mathrm{g} / \mathrm{L}$ & $<0.2$ \\
\hline 2,2-dichloropropane, total & $\mu \mathrm{g} / \mathrm{L}$ & $<0.2$ \\
\hline 1,1-dichloropropene, total & $\mu \mathrm{g} / \mathrm{L}$ & $<0.2$ \\
\hline cis-1,3-dichloropropene, total & $\mu \mathrm{g} / \mathrm{L}$ & $<0.2$ \\
\hline trans-1,3-dichloropropene, total & $\mu \mathrm{g} / \mathrm{L}$ & $<0.2$ \\
\hline Dieldrin, dissolved & $\mu \mathrm{g} / \mathrm{L}$ & $<0.02$ \\
\hline Dieldrin, total & $\mu \mathrm{g} / \mathrm{L}$ & $<0.010$ \\
\hline $\begin{array}{l}\text { 2,6-diethylaniline, filtered } 0.7 \mu \text { glass fiber, } \\
\text { recoverable }\end{array}$ & $\mu \mathrm{g} / \mathrm{L}$ & $<0.01$ \\
\hline Deethylatrazine, dissolved, recoverable & $\mu \mathrm{g} / \mathrm{L}$ & $<0.02$ \\
\hline Diethylphthalate, total & $\mu g / L$ & $<5.0$ \\
\hline $\begin{array}{l}\text { Dimethoate, dissolved } 0.7 \mu \text { glass fiber, } \\
\text { recoverable }\end{array}$ & $\mu \mathrm{g} / \mathrm{L}$ & $<0.02$ \\
\hline 2,4-dimethylphenol, total & $\mu \mathrm{g} / \mathrm{L}$ & $<5.0$ \\
\hline Dimethyl phthalate, total & $\mu \mathrm{g} / \mathrm{L}$ & $<5.0$ \\
\hline Di-n-butyl phthalate, total & $\mu \mathrm{g} / \mathrm{L}$ & $<5.0$ \\
\hline 4,6-dinitro-o-cresol, total & $\mu \mathrm{g} / \mathrm{L}$ & $<30.0$ \\
\hline 2,4-dinitrophenol & $\mu \mathrm{g} / \mathrm{L}$ & $<20.0$ \\
\hline 2,4-dinitrotoluene, total & $\mu \mathrm{g} / \mathrm{L}$ & $<5.0$ \\
\hline 2,6-dinitrotoluene, total & $\mu \mathrm{g} / \mathrm{L}$ & $<5.0$ \\
\hline Di-n-octylphthalate, total & $\mu \mathrm{g} / \mathrm{L}$ & $<10.0$ \\
\hline 1,2-diphenylhydrazine, total, recoverable & $\mu \mathrm{g} / \mathrm{L}$ & $<5.0$ \\
\hline Disulfoton, dissolved 0.7 , recoverable & $\mu \mathrm{g} / \mathrm{L}$ & $<0.02$ \\
\hline Disyston, total & $\mu \mathrm{g} / \mathrm{L}$ & $<0.01$ \\
\hline Endosulfan, total & $\mu \mathrm{g} / \mathrm{L}$ & $<0.010$ \\
\hline Endrin, total, recoverable & $\mu \mathrm{g} / \mathrm{L}$ & $<0.010$ \\
\hline $\begin{array}{l}\text { EPTC, dissolved } 0.7 \mu \text { glass fiber, } \\
\text { recoverable }\end{array}$ & $\mu \mathrm{g} / \mathrm{L}$ & $<0.005$ \\
\hline $\begin{array}{l}\text { Ethalfluralin, dissolved } 0.7 \mu \text { glass fiber, } \\
\text { recoverable }\end{array}$ & $\mu g / L$ & $<0.01$ \\
\hline Ethion, total & $\mu \mathrm{g} / \mathrm{L}$ & $<0.01$ \\
\hline
\end{tabular}


Table 5. Laboratory measured water-quality properties, bacteria counts, major ion and nutrient concentrations, trace-element and radionuclide concentrations, and organic compound concentrations in a ground-water sample collected February 1, 1994, from test well TW-4 completed in the North Canadian River alluvium, Concho Reserve, Canadian County, Oklahoma - Continued

\begin{tabular}{|c|c|c|}
\hline Constituent name & Units & Value \\
\hline $\begin{array}{l}\text { Ethoprop, dissolved } 0.7 \mu \text { glass fiber, } \\
\text { recoverable }\end{array}$ & $\mu \mathrm{g} / \mathrm{L}$ & $<0.01$ \\
\hline Ethylbenzene, total & $\mu \mathrm{g} / \mathrm{L}$ & $<0.2$ \\
\hline bis (2-ethylhexyl) phthalate, total, & $\mu \mathrm{g} / \mathrm{L}$ & $<5.0$ \\
\hline Fluoranthene, total & $\mu \mathrm{g} / \mathrm{L}$ & $<5.0$ \\
\hline Fluorene, total & $\mu \mathrm{g} / \mathrm{L}$ & $<5.0$ \\
\hline Fonofos, dissolved, recoverable & $\mu \mathrm{g} / \mathrm{L}$ & $<0.01$ \\
\hline Fonofos (dyfonate) total, recoverable & $\mu \mathrm{g} / \mathrm{L}$ & $<0.01$ \\
\hline Freon 113, total, recoverable & $\mu \mathrm{g} / \mathrm{L}$ & $<0.5$ \\
\hline Heptachlor epoxide, total & $\mu \mathrm{g} / \mathrm{L}$ & $<0.010$ \\
\hline Heptachlor, total & $\mu \mathrm{g} / \mathrm{L}$ & $<0.010$ \\
\hline Hexachlorobenzene, total & $\mu \mathrm{g} / \mathrm{L}$ & $<5.0$ \\
\hline Hexachlorobutadiene, total & $\mu \mathrm{g} / \mathrm{L}$ & $<0.2$ \\
\hline Hexachlorocyclopentadiene, total & $\mu \mathrm{g} / \mathrm{L}$ & $<5.0$ \\
\hline Hexachloroethane, total & $\mu \mathrm{g} / \mathrm{L}$ & $<5.0$ \\
\hline Indeno $(1,2,3-c d)$ pyrene, total & $\mu \mathrm{g} / \mathrm{L}$ & $<10.0$ \\
\hline Isophorone, total & $\mu \mathrm{g} / \mathrm{L}$ & $<5.0$ \\
\hline Isopropylbenzene, total, recoverable & $\mu \mathrm{g} / \mathrm{L}$ & $<0.20$ \\
\hline$p$-isopropyltoluene, total, recoverable & $\mu \mathrm{g} / \mathrm{L}$ & $<0.20$ \\
\hline Lindane, dissolved & $\mu \mathrm{g} / \mathrm{L}$ & $<0.01$ \\
\hline Lindane, total & $\mu \mathrm{g} / \mathrm{L}$ & $<0.010$ \\
\hline $\begin{array}{l}\text { Linuron, dissolved } 0.7 \mu \text { glass fiber, } \\
\text { recoverable }\end{array}$ & $\mu \mathrm{g} / \mathrm{L}$ & $<0.04$ \\
\hline Malathion, dissolved & $\mu \mathrm{g} / \mathrm{L}$ & $<0.01$ \\
\hline Malathion, total & $\mu \mathrm{g} / \mathrm{L}$ & $<0.01$ \\
\hline Mesitylene, total, recoverable & $\mu \mathrm{g} / \mathrm{L}$ & $<0.20$ \\
\hline Methoxychlor, total & $\mu \mathrm{g} / \mathrm{L}$ & $<0.01$ \\
\hline $\begin{array}{l}\text { Methylazinphos, dissolved } 0.7 \mu \text { glass fiber, } \\
\text { recoverable }\end{array}$ & $\mu \mathrm{g} / \mathrm{L}$ & $<0.04$ \\
\hline Methyl bromide, total & $\mu \mathrm{g} / \mathrm{L}$ & $<0.2$ \\
\hline Methyl chloride, total & $\mu \mathrm{g} / \mathrm{L}$ & $<0.2$ \\
\hline Methylene chloride, total & $\mu \mathrm{g} / \mathrm{L}$ & $<0.2$ \\
\hline $\begin{array}{l}\text { Methyl parathion, dissolved } 0.7 \mu \text { glass fiber, } \\
\text { recoverable }\end{array}$ & $\mu \mathrm{g} / \mathrm{L}$ & $<0.03$ \\
\hline Methyl parathion, total & $\mu \mathrm{g} / \mathrm{L}$ & $<0.01$ \\
\hline Metolachlor, dissolved & $\mu \mathrm{g} / \mathrm{L}$ & $<0.01$ \\
\hline Metribuzin, (Sencor), dissolved & $\mu \mathrm{g} / \mathrm{L}$ & $<0.01$ \\
\hline Mirex, total & $\mu \mathrm{g} / \mathrm{L}$ & $<0.01$ \\
\hline $\begin{array}{l}\text { Molinate, dissolved } 0.7 \mu \text { glass fiber } \\
\text { recoverable }\end{array}$ & $\mu \mathrm{g} / \mathrm{L}$ & $<0.01$ \\
\hline Naphthalene, total & $\mu \mathrm{g} / \mathrm{L}$ & $<0.2$ \\
\hline
\end{tabular}


Table 5. Laboratory measured water-quality properties, bacteria counts, major ion and nutrient concentrations, trace-element and radionuclide concentrations, and organic compound concentrations in a ground-water sample collected February 1, 1994, from test well TW-4 completed in the North Canadian River alluvium, Concho Reserve, Canadian County, Oklahoma - Continued

\begin{tabular}{|c|c|c|}
\hline Constltuent name & Unlts & Value \\
\hline $\begin{array}{l}\text { Napropamide, dissolved } 0.7 \mu \text { glass fiber, } \\
\text { recoverable }\end{array}$ & $\mu \mathrm{g} / \mathrm{L}$ & $<0.01$ \\
\hline Nitrobenzene, total & $\mu \mathrm{g} / \mathrm{L}$ & $<5.0$ \\
\hline 2-nitrophenol, total & $\mu \mathrm{g} / \mathrm{L}$ & $<5.0$ \\
\hline 4-nitrophenol, total & $\mu \mathrm{g} / \mathrm{L}$ & $<30.0$ \\
\hline$n$-nitrosodimethylamine, total & $\mu \mathrm{g} / \mathrm{L}$ & $<5.0$ \\
\hline$n$-nitrosodi- $n$-propylamine, total & $\mu \mathrm{g} / \mathrm{L}$ & $<5.0$ \\
\hline$n$-nitrosodiphenylamine, total & $\mu \mathrm{g} / \mathrm{L}$ & $<5.0$ \\
\hline Parachlorometacresol, total & $\mu \mathrm{g} / \mathrm{L}$ & $<30.0$ \\
\hline Parathion, dissolved & $\mu \mathrm{g} / \mathrm{L}$ & $<0.02$ \\
\hline Parathion, total & $\mu \mathrm{g} / \mathrm{L}$ & $<0.01$ \\
\hline PCBs, total & $\mu \mathrm{g} / \mathrm{L}$ & $<0.1$ \\
\hline $\begin{array}{l}\text { Pebulate, dissolved } 0.7 \mu \text { glass fiber, } \\
\text { recoverable }\end{array}$ & $\mu \mathrm{g} / \mathrm{L}$ & $<0.01$ \\
\hline $\begin{array}{l}\text { Pendimethalin, dissolved } 0.7 \mu \text { glass fiber, } \\
\text { recoverable }\end{array}$ & $\mu \mathrm{g} / \mathrm{L}$ & $<0.02$ \\
\hline $\begin{array}{l}\text { cis-permethrin, dissolved } 0.7 \mu \text { glass fiber, } \\
\text { recoverable }\end{array}$ & $\mu \mathrm{g} / \mathrm{L}$ & $<0.02$ \\
\hline Perthane, total & $\mu \mathrm{g} / \mathrm{L}$ & $<0.1$ \\
\hline Pentachlorophenol, total & $\mu \mathrm{g} / \mathrm{L}$ & $<30.0$ \\
\hline Phenanthrene, total & $\mu \mathrm{g} / \mathrm{L}$ & $<5.0$ \\
\hline Phenol $\left(\mathrm{C}_{6} \mathrm{H}_{5} \mathrm{OH}\right)$, total & $\mu g / L$ & $<5.0$ \\
\hline $\begin{array}{l}\text { Phorate, dissolved } 0.7 \mu \text { glass fiber, } \\
\text { recoverable. }\end{array}$ & $\mu \mathrm{g} / \mathrm{L}$ & $<0.02$ \\
\hline Phorate, total & $\mu g / L$ & $<0.01$ \\
\hline Polychlorinated naphthalenes, total & $\mu \mathrm{g} / \mathrm{L}$ & $<0.10$ \\
\hline Prometon, dissolved, recoverable & $\mu \mathrm{g} / \mathrm{L}$ & $<0.01$ \\
\hline $\begin{array}{l}\text { Pronamide, dissolved } 0.7 \mu \text { glass fiber, } \\
\text { recoverable }\end{array}$ & $\mu \mathrm{g} / \mathrm{L}$ & $<0.01$ \\
\hline Propachlor, dissolved, recoverable & $\mu \mathrm{g} / \mathrm{L}$ & $<0.02$ \\
\hline $\begin{array}{l}\text { Propanil, dissolved } 0.7 \mu \text { glass fiber, } \\
\text { recoverable }\end{array}$ & $\mu \mathrm{g} / \mathrm{L}$ & $<0.02$ \\
\hline $\begin{array}{l}\text { Propargite, dissolved } 0.7 \mu \text { glass fiber, } \\
\text { recoverable }\end{array}$ & $\mu \mathrm{g} / \mathrm{L}$ & $<0.01$ \\
\hline n-propylbenzene, total, recoverable & $\mu \mathrm{g} / \mathrm{L}$ & $<0.20$ \\
\hline Pseudocumene, total, recoverable & $\mu \mathrm{g} / \mathrm{L}$ & $<0.20$ \\
\hline Pyrene, total & $\mu \mathrm{g} / \mathrm{L}$ & $<5.0$ \\
\hline Simazine, dissolved, recoverable & $\mu \mathrm{g} / \mathrm{L}$ & $<0.01$ \\
\hline Styrene, total & $\mu \mathrm{g} / \mathrm{L}$ & $<0.2$ \\
\hline $\begin{array}{l}\text { Tebuthiuron, dissolved } 0.7 \mu \text { glass fiber, } \\
\text { recoverable }\end{array}$ & $\mu \mathrm{g} / \mathrm{L}$ & $<0.02$ \\
\hline $\begin{array}{l}\text { Terbacil, dissolved } 0.7 \mu \text { glass fiber, } \\
\text { recoverable }\end{array}$ & $\mu \mathrm{g} / \mathrm{L}$ & $<0.03$ \\
\hline
\end{tabular}


Table 5. Laboratory measured water-quality properties, bacteria counts, major ion and nutrient concentrations, trace-element and radionuclide concentrations, and organic compound concentrations in a ground-water sample collected February 1, 1994, from test well TW-4 completed in the North Canadian River alluvium, Concho Reserve, Canadian County, Oklahoma - Continued

\begin{tabular}{lll}
\hline \multicolumn{1}{c}{ Constituent name } & Unlts & Value \\
\hline $\begin{array}{l}\text { Terbufos, dissolved 0.7 } \mu \text { glass fiber, } \\
\text { recoverable }\end{array}$ & $\mu \mathrm{g} / \mathrm{L}$ & $<0.01$ \\
Tert-butylbenzene, total, recoverable & $\mu \mathrm{g} / \mathrm{L}$ & $<0.20$ \\
Tert-butyl methyl ether, total, recoverable & $\mu \mathrm{g} / \mathrm{L}$ & $<1.0$ \\
1,1,1,2-tetrachloroethane, total, recoverable & $\mu \mathrm{g} / \mathrm{L}$ & $<0.2$ \\
1,1,2,2-tetrachloroethane, total, recoverable & $\mu \mathrm{g} / \mathrm{L}$ & $<0.2$ \\
Tetrachloroethylene, total & $\mu \mathrm{g} / \mathrm{L}$ & $<0.2$ \\
Thiobencarb, dissolved 0.7 $\mu$ glass fiber, & $\mu \mathrm{g} / \mathrm{L}$ & $<0.01$ \\
recoverable & & \\
Toluene, total & $\mu \mathrm{g} / \mathrm{L}$ & $<0.2$ \\
Toxaphene, total & $\mu \mathrm{g} / \mathrm{L}$ & $<1$ \\
Triallate, dissolved 0.7 $\mu$ glass fiber, & $\mu \mathrm{g} / \mathrm{L}$ & $<0.01$ \\
recoverable & & \\
1,2,3-trichlorobenzene, total & $\mu \mathrm{g} / \mathrm{L}$ & $<0.20$ \\
1,2,4-trichlorobenzene, total, recoverable & $\mu \mathrm{g} / \mathrm{L}$ & $<0.20$ \\
1,1,1-trichloroethane, total & $\mu \mathrm{g} / \mathrm{L}$ & $<0.2$ \\
1,1,2-trichloroethane, total & $\mu \mathrm{g} / \mathrm{L}$ & $<0.2$ \\
Trichloroethylene, total & $\mu \mathrm{g} / \mathrm{L}$ & $<0.2$ \\
Trichlorofluoromethane, total & $\mu \mathrm{g} / \mathrm{L}$ & $<0.2$ \\
2,4,6-trichlorophenol, total & $\mu \mathrm{g} / \mathrm{L}$ & $<20.0$ \\
1,2,3-trichloropropane, total & $\mu \mathrm{g} / \mathrm{L}$ & $<0.2$ \\
Trifluralin, dissolved 0.7 $\mu$ glass fiber, & $\mu \mathrm{g} / \mathrm{L}$ & $<0.01$ \\
recoverable & & $<0.01$ \\
Trithion, total & $\mu \mathrm{g} / \mathrm{L}$ & $<0.2$ \\
Vinyl chloride, total & $\mu \mathrm{g} / \mathrm{L}$ & $<0.20$ \\
Xylenes, total, recoverable & $\mu \mathrm{g} / \mathrm{L}$ & \\
\hline & & \\
\hline
\end{tabular}

